\title{
Effect of Inoculation with Biofertilizers and Molybdenum on the Growth and Productivity of Faba Bean (vicia faba l.) Grown in Sandy Soil under Drip Irrigation \\ Dalal H. Sary ${ }^{1}$, Enga M. Niel ${ }^{2}$ and Noha M. Abdelhameid ${ }^{3}$
}

\begin{abstract}
Field experiments were carried out during 2016/2017 and 2017/2018 growing winter seasons using sandy soil under drip irrigation system, at Ali Mubark Experimental Farm, South Tahrir Region, Egypt. The experimental layout was carried out to provide complete randomized blocks in a split- plot design. The objective of this study to investigate the effect of application of foliar ammonium molybdate in combination with inoculation with biological fertilizers: Mycorrhiza (Glomus sp.) and Rhizobium (Rhizobium leguminosarum) on the growth performance and productivity of Faba bean (Vicia faba L.) plant grown in sandy soil under drip irrigation. The main treatments included foliar application of ammonium molybdate (+Mo) and without ammonium molybdate (-Mo) at rates of $5 \mathrm{mg} \mathrm{Mo} \mathrm{/l}$ and $0 \mathrm{mg} \mathrm{Mo/l,} \mathrm{respectively.} \mathrm{The} \mathrm{sub} \mathrm{main}$ treatments included four treatments (i) biological fertilizer Mycorrhiza, (ii) Rhizobia, (iii) Mix between the two biofertilizers and (iv) without biofertilizers inoculation. The obtained results indicated that treatment with Mo recorded high values of all parameters as compared to without Mo. Application of biofertilizer improved all growth characters, available of $\mathrm{N}, \mathrm{P}, \mathrm{K}, \mathrm{O} . \mathrm{M}$. and soil respiration. The most effective treatment was obtained by the mixed RIZB/MYCO treatment followed by RIZB for $\mathrm{N}, \mathrm{K}$ and by MYCO for P, O.M. and soil respiration. The upper soil layer $(0-30 \mathrm{~cm})$ contained high values of available $N$ or $P, O . M$ and soil respiration while available $P$ increased in the lower layer $(30-60 \mathrm{~cm})$. Macro elements $(\mathbf{N}, \mathbf{P}, \mathrm{K})$ contents in leaves and grains showed high response to addition of ammonium molybdate with the mixed RIZB/MYCO treatments followed by RIZB for $\mathbf{N}$ and protein, also MYCO for $K$ and $P$ content. Vegetative growth characters and yield components of Faba bean plant showed high response to the mixed RIZB/MYCO treatment followed by MYCO treatment. The results showed that Myco infection had enhanced with MYCO treatment while Nitrogenase activity was enhanced with RIZB treatment for Faba bean plant grown under sandy soil and drip irrigation conditions.
\end{abstract}

Keywords: ammonium molybdate, Mycorrhiza, Rhizobium, inoculation, foliar application, Faba bean, sandy soil.

\section{INTRODUCTION}

Legumes are the major sources of proteins for both man and livestock, especially in developing countries, where animal's protein is expensive (Mohamed, 2010). Egypt is pressing hard to increase crop productivity because crop productions did not match with population consumptions. The newly reclaimed lands in the country are brought into Faba bean cultivation for increasing its production horizontally. Faba bean (Vicia faba L.) is one of the most important winter crops of high nutritive value in the world as well as in Egypt. Karkanis et al., (2018) reported that Faba beans are highly nutritious because of their high protein content and are a respectable source of mineral nutrients (calcium and iron), vitamins, starch, cellulose and numerous bioactive compounds. Also, the contribution of Faba bean in maintaining the sustainability of agricultural systems. The low soil fertility of the newly reclaimed lands is still the main production constraints (Khatab, 2016). Mona et al., (2011) found that Faba bean has a potential atmospheric $\mathrm{N}_{2}$-fixing capacity and exhibits high levels of protein (28-36\%) in the grains for human consumptions and therefore it has an important role in improving the fertility of soil. Bakry et al., (2011) reported that production of Faba bean in Egypt is limiting and is affected by different factors such as soil fertility and water supply.

Barman et al., (2016) reported that the mycorrhizal association is one of nature's benefits for sustainable agriculture. It is one of the best examples of symbiotic association between plants and fungi, and helps the host plants to succeed in adverse soil conditions and drought situations by increasing the root surface and mineral uptake efficiency. Khalil et al., (2014) found that when the amount of available phosphorus in soil is low, mycorrhiza colonize the cortical tissue of roots of most plant species and thus increase the root surface area and minerals uptake such as $\mathrm{N}, \mathrm{P}, \mathrm{K}, \mathrm{Ca}, \mathrm{S}, \mathrm{Cu}, \mathrm{Zn}$ and other microelements from the soil. Ghorbanian et al., (2011) mentioned that Mycorrhiza fungi extend their root absorbing area through their mycelium network and

DOI: $10.21608 / a s e j a i q j s a e .2020 .81530$

${ }^{1}$ Sandy and Calcareous Soil Department, Soil, Water \& Environment Institute, Agriculture Research Center, Egypt.

2. Soils Fertility and Plant Nutrition Department, Soil, Water \& Environment

Institute, Agriculture Research Center, Egypt.

3. Soil Fertility and Microbiology Department, Desert Research Center, Egypt.

Received February29, 2020, Accepted March26, 2020 
change unavailable phosphorus into available form and transport it to root system causing increases in plant growth.

Pandeeswari and Kalaiarasu (2017) revealed that Rhizobium have high capacity to fix atmospheric nitrogen in symbiosis with the plants of the family of legumes. Bacteria of family Rhizobiaceae are symbiotic and efficiently convert atmospheric nitrogen to ammonia which is utilized by the host (Okazaki et al., 2004). Biological nitrogen fixation has a great importance as a non-polluting and a cost-effective method to improve soil fertility through supplying nitrogen to different agricultural systems (Youseif et al., 2017).

Vesicular Arbuscular mycorrhiza and rhizobia had restricted potential yields of Faba bean cultivation. Mohamed and Gomaa (2005) reported that biomicrobial strains are essential since the native rhizobia are incapable of supporting satisfactory levels of N2 fixation. The beneficial effect of inoculation with rhizobia and Vesicular Arbuscular mycorrhiza has been reported for Faba bean (Rizk and Shafeek, 2000). Thus, biological $\mathrm{N}$-fixation a main resource of $\mathrm{N}$, may represent one of the possible solutions and a great possibility for sustainable production of grain legumes (Mfilinge et al., 2014). Schütz et al., (2018) indicated that Arbuscular Mycorrhiza Fungi and application of biofertilizers with both functional behaviors $\mathrm{N}$ fixation and $\mathrm{P}$ solubilization were the most effective inoculants. The mixture between these microbes was more effective than the separate application of each biofertilizer alone. The beneficial combination effects of bacteria with fungi have been reported by Patreze and Cordeiro (2004) who found that these bacteria may affect fungi and plant host through different mechanisms that affect receptivity of root, root-fungus recognition, fungal growth, modification of chemistry for rhizospheric soil, and germination of the fungal propagules. Kafle et al., (2019) reported that Arbuscular Mycorrhizal Fungi and phosphate-solubilizing bacteria have a major role in natural and agro-ecosystems, and their use as bioinoculants is an increasing tendency in agricultural practices.

Molybdenum is part of the enzyme nitrogenase contained within symbiotic Bradyrhizobium bacteria, which are responsible for fixing nitrogen in legumes (Crusciol et al., 2019). Foliar Molybdenum application enhanced the growth and nutritional status of common bean (Eduardo et al., 2010). Ndakidemi et al., (2011) reported that efficient uptake of micronutrients was recorded with treatments involving high application rate of Mo (12 g/kg of seeds). The objectives of this study, therefore, were to investigate the response of Faba been plant to application foliar of ammonium molybdate in combination inoculation with biological fertilizers: Mycorrhiza and Rhizobium on the growth performance and productivity of Faba bean plant grown in sandy soil under drip irrigation.

\section{MATERIALS AND METHODS}

\section{Experimental layout}

Field experiments were carried out during the winter seasons 2016/2017 and 2017/2018 at El-Bostan area, Ali Mubark Farm at South Tahrir Region, Egypt. The experimental soil is sandy and method of irrigation was drip system. The main physical and chemical properties of the soil in the two seasons are shown in Table 1. The seeds of Faba bean (Vicia faba L.) variety Nubaria 1 were obtained from Agric. Res. St, El Giza, MALR. The seeds were treated with rhizobium bacteria (proper symputic bacteria), at 15 November of each growth season, sown within $30 \mathrm{~cm}$ in between plants in row and $80 \mathrm{~cm}$ apart (El Habbasha et al., 2007). The main treatments included foliar application by molybdenum in two doses: without (-Mo) and with $(+\mathrm{Mo})$ at rates of $5 \mathrm{mg}$ Mo $/ \mathrm{l}$ as ammonium molybdate. The sub- main treatments were the control, biological fertilizers: Mycorrhiza (MYCO), Rhizobia (RIZB) and Mixed of both (MYCO/ RIZB). The Mycorrhiza strain was Glomus sp., and that of Rhizobium was Rhizobium leguminosarum. These strains were grown according to the methods outlined by Norris and Date (1976) and Attia et al., (2003). The experimental design was complete randomized blocks in a split- plot. Each treatment was carried out in triplicates and therefore the total numbers of experimental plots were $24(2 * 4 * 3)$.

Inorganic fertilizers were applied to the soil as follows: Superphosphate $\left(15.5 \% \mathrm{P}_{2} \mathrm{O}_{5}\right)$ at rate of 150 $\mathrm{kg} / \mathrm{fed}$ before sowing, potassium sulphate $\left(48 \% \mathrm{~K}_{2} \mathrm{O}\right.$, ) at a rate of $50 \mathrm{~kg} / \mathrm{fed}$ before sowing, ammonium sulphate $(20.5 \% \mathrm{~N})$ at a rate of $20 \mathrm{~kg} / \mathrm{fed}$ at early stage of plant growth. All cultivation practices (i.e., weeds and diseases control, etc...) were carried out and following the common field practices recommended by the Ministry of Agriculture and Land Reclamation (MALR) for Faba bean. 
Table 1. The mean values of the physical and chemical properties of the used soils in the two growing seasons

\begin{tabular}{|c|c|c|c|c|c|c|c|c|c|}
\hline \multirow{2}{*}{$\begin{array}{c}\text { Soil parameter } \\
\text { Season } \\
\end{array}$} & \multicolumn{2}{|c|}{$\begin{array}{c}\text { Particle size distribution } \\
\%\end{array}$} & \multirow[t]{2}{*}{$\begin{array}{c}\text { EC } \\
\mathrm{dSm}^{-1}\end{array}$} & \multirow[t]{2}{*}{$\mathbf{p H}$} & \multirow[t]{2}{*}{$\begin{array}{c}\mathrm{CaCO}_{3} \\
\%\end{array}$} & \multirow[t]{2}{*}{$\begin{array}{c}\text { OM } \\
\%\end{array}$} & \multicolumn{3}{|c|}{$\begin{array}{c}\text { Available nutrient } \\
(\mathrm{mg} / \mathrm{kg})\end{array}$} \\
\hline & & & & & & & $\mathbf{N}$ & $\mathbf{P}$ & $\mathbf{K}$ \\
\hline \multirow{4}{*}{$2016 / 2017$} & Sand & 91.5 & & & & & & & \\
\hline & Clay & 4.1 & 0.36 & 8.7 & 5.1 & 0.1 & 10.6 & 2.5 & 15.5 \\
\hline & Silt & 4.4 & & & & & & & \\
\hline & Texture class & Sandy & & & & & & & \\
\hline \multirow{4}{*}{$2017 / 2018$} & Sand & 92.0 & & & & & & & \\
\hline & Clay & 5.0 & 0.34 & 8.6 & 4.0 & 0.19 & 12.1 & 3.1 & 18.0 \\
\hline & Silt & 3.0 & & & & & & & \\
\hline & Texture cla & Sand & & & & & & & \\
\hline
\end{tabular}

\section{Sampling:}

Soil: Rhizosphere soil samples $(0-30$ and $30-60 \mathrm{~cm})$ were collected at plant harvest for determining the number of Arbuscular mycorrhizal (AM) spores and Bradyrhizobium count, and for soil physical, chemical and biological constituents.

Plant: Plant samples (3plants/plot) were taken at harvest, washed by tap water, then by distilled water, oven dried at $70^{\circ}$ for $48 \mathrm{hrs}$, finely ground using stainless steel mill and preserved for analysis (Chapman and Pratt, 1961). The morphological characters and yield components of the plant were carried out using plant at physiological maturity. These included plant height $(\mathrm{cm})$, weight of plant(gm/plant), number of branches/plant, root length $(\mathrm{cm})$, weight of $\operatorname{root}(\mathrm{gm})$, number of nodules/plant, weight of nodules (gm), number of pods/ plant, weight of 100 grains (gm), and weight of grains/plant(gm) and grains yield (t/ha).

\section{Analysis:}

Soil: The amounts of available $\mathrm{N}$ in soil was determined by Kjeldahl method, the amount of available phosphorus in soil was determined as described by Olsen et al., (1954) and the concentration of $\mathrm{P}$ was measured colorimetrically using the ascorbic acid method (Olsen and Watanabe 1965), and available K was extracted with neutral normal $\mathrm{NH}_{4}$-Acetate and measured by flame photometer (Black, 1965 and Cottenie et al., 1982). The amount of organic matter was determined by Walkley- Black method (Black, 1965), and calculated as follows: O. M $(\%)=($ O.C \% x 1.72). Total carbonate was measured by calcimeter (Alison and Moodle, 1965). Soil respiration was measured by the elevation of $\mathrm{CO} 2$ procedure (Kaloosh, 1978). The particle size distribution (sand, silt and clay) was measured by hydrometer method (FAO, 1970). The electrical conductivity (E.C) was measured in saturated soil water extract and $\mathrm{pH}$ was measured in 1:2.5 soil water suspension by pH- Meter (Jackson, 1973).
Plant: The oven-dried plant material was subjected to wet digestion using $\mathrm{H}_{2} \mathrm{SO}_{4}$ and $\mathrm{H}_{2} \mathrm{O}_{2}$ (Cottenie et al., 1982). Total nitrogen was determined using micro kjeldahl method (Bremner and Mulvaney, 1982). The concentration of protein was obtained by multiplying total $\mathrm{N}$ by 6.25 as a standard factor. Total phosphorus was determined colorimetrically using VanadoMolybdate yellow color method (Jackson, 1973) and total potassium was measured by Flame photometer (Page et al., 1982).

Assessment of VA-mycorrhizal infection was measured in composite root sample of three plants per plot, by using the staining method of Phillips and Haymen (1970). The gridlines intersect method of Giovannetti and Mosse, (1980) was used for microscopic examination to estimate the VAmycorrhizal infection percentage as follows:

Mycorrhizal Colonization $(96)=$

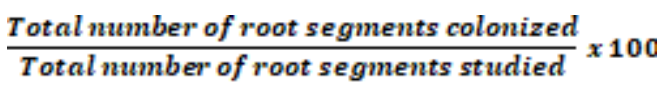

The number of VAM spores in soil rhizosphere was determined by wet sieving and decantation. Samples were centrifuged and permanent slides were prepared according to Schenck and Perez (1990). The strains of rhizobia were isolated from root nodules of Vicia faba. The isolates were grown on yeast extract mannitol agar (YEMA) medium and incubated at $28{ }^{\circ} \mathrm{C}$ (Vincent, 1970) on an orbital shaker at 120 rev per min for three days. The growth response of bacterial isolates at $\mathrm{pH} 9$ and evaluate the OD at $600 \mathrm{~nm}$ using Unico UV-2100 spectrophotometer. Nitrogenase activity was determined in a separate root system using gas chromatograph (Thermo Scientific TRACE GC Ultra equipped with FID detector and Capillary column CP-Pora BOND Uf used silica plot $25 \mathrm{~m} \times 0.32 \mathrm{~mm}, \mathrm{df}=7-\mathrm{m}$ ) as described by Abd-Alla et al., (2013).

Statistical analysis: The obtained data were subjected to statistical analysis as described by Snedecor and Cochran (1990). 


\section{RESULTS AND DISCUSSION}

\section{Soil}

\section{Available N, P, and $K$ in soil}

Available N: Table 2 showed a significant increase in the mean values of available $\mathrm{N}$ in the control treatment of soil (no Mo addition) as a result of application of RIZB and mixed RIZB/ MYCO. The highest increase was due to RIZB and to mixed RIZB/ MYCO relative to MYCO treatment. It is clear that the amount of available $\mathrm{N}$ in soil was higher in the upper layer $(0-30 \mathrm{~cm})$ than in that of the lower layer $(30-60 \mathrm{~cm})$ under all treatments including the control.

Foliar application by molybdenum with $5 \mathrm{mg} / \mathrm{l} \mathrm{Mo}$, the available $\mathrm{N}$ in soil significantly increased as a result of treatment by RIZB and MYCO or mixed RIZB/ MYCO as compared to the control. The highest amount of available $\mathrm{N}$ was found in soil treated with the mixed RIZB/ MYCO, followed by RIZB and then by MYCO. The amount of available $\mathrm{N}$ in soil was almost higher in the top soil $(0-30 \mathrm{~cm})$ than in the lower soil $(30-60 \mathrm{~cm})$ except with mix RIZB/ MYCO treatment. The mean value of available $\mathrm{N}$ in the soil collected in the first growing season were approximately close especially in the upper layer of soil $(0-30 \mathrm{~cm})$ as shown in Table 2 . Molybdenum addition stimulated the status of available $\mathrm{N}$. The mean value of available $\mathrm{N}$ in soil of the upper layer $(0-30 \mathrm{~cm})$ increased from $94.9 \mathrm{mg} / \mathrm{kg}$, in soil without Mo application, to $109.9 \mathrm{mg} / \mathrm{kg}$ in soil with Mo.
The results in (Fig 1) showed that due to application of Mo, the amount of available $\mathrm{N}$ was the highest in RIZB soil, and RIZB + MYCO treatments.

Available P: Table 2 showed significant increase in the concentration of available $\mathrm{P}$ in soil of the upper layer (0$30 \mathrm{~cm}$ ) without Mo, foliar spray, from $6.83 \mathrm{mg} / \mathrm{kg}$ to $7.74 \mathrm{mg} / \mathrm{kg}, 8.17 \mathrm{mg} / \mathrm{kg}$, and $8.77 \mathrm{mg} / \mathrm{kg}$ as a result of treatment by RIZB, MYCO and by mixed RIZB / MYCO, respectively. There are no significant variations in the concentrations of available $\mathrm{P}$ in soils of the upper and lower layer. In the case of foliar spray by $5 \mathrm{Mo}$ $\mathrm{mg} / \mathrm{l}$, the amounts of available $\mathrm{P}$ in soils of the upper soil layer significantly increased as a result of treatment by RIZB (10.01 mg/kg), MYCO (11.94 mg/kg), or mixed RIZB/ MYCO (13.35 mg/kg)as compared to the control $(9.15 \mathrm{mg} / \mathrm{kg})$. There are no significant variations in the concentrations of available $\mathrm{P}$ in soil layers due treatment by RIZB and MYCO except by mixed RIZB/ MYCO. The results indicate that Mo treatment significantly increased the amount of available $\mathrm{P}$ in soils as compared to without Mo treatments. In the control soil the amount of available $\mathrm{P}$ in the upper soil layer significantly increased from 6.83 to $7.88 \mathrm{mg} / \mathrm{kg}$ (as a mean value) due biofertilizers treatments. Application of biofertilizer in combination with Mo significantly increased the amount of available $\mathrm{P}$ in soils to the extent that these soils contained more than the adequate level of available $\mathrm{P}$ in soil

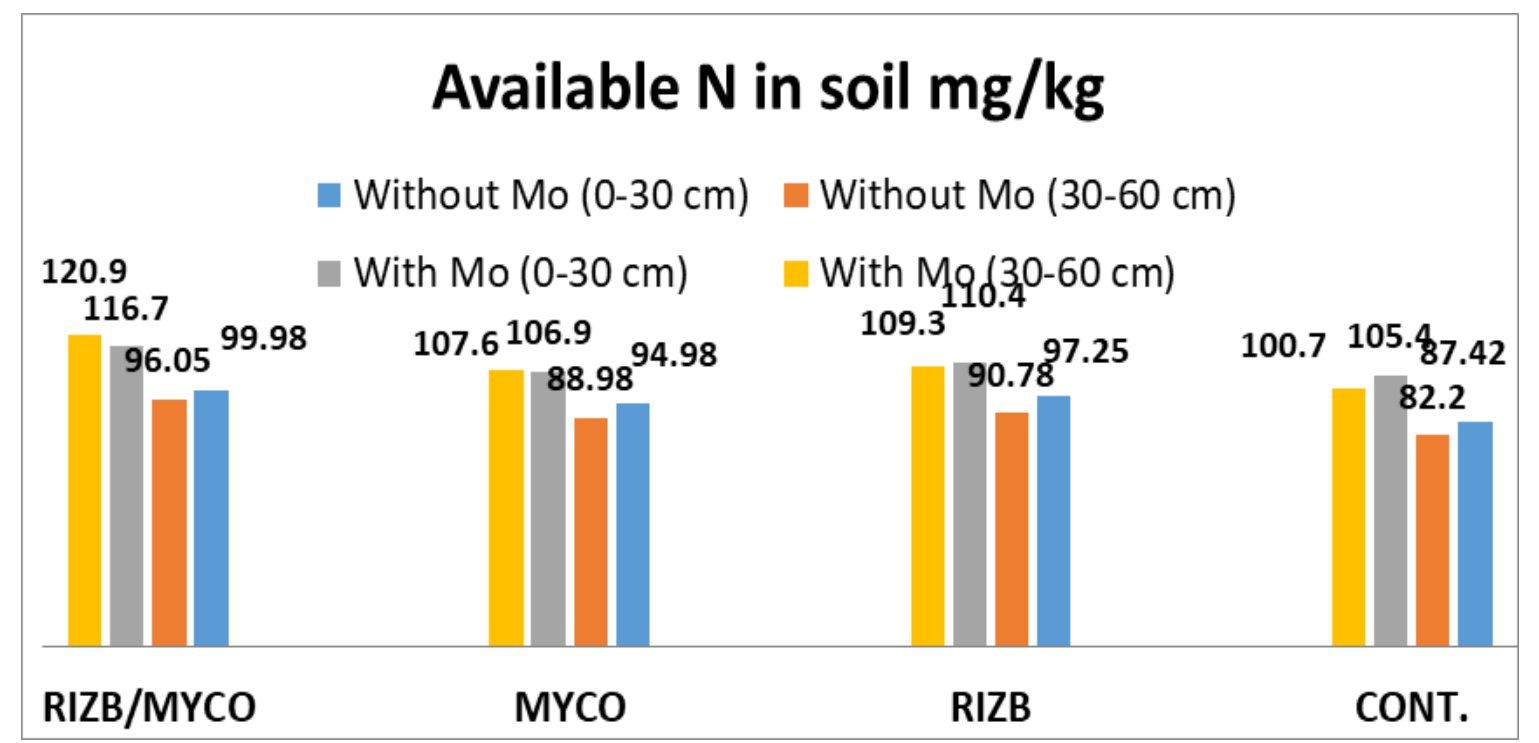

Fig. 1. Available $\mathbf{N}$ in soil as influenced by different treatments of biofertilizers without and with Mo foliar application (means of two successive seasons) 


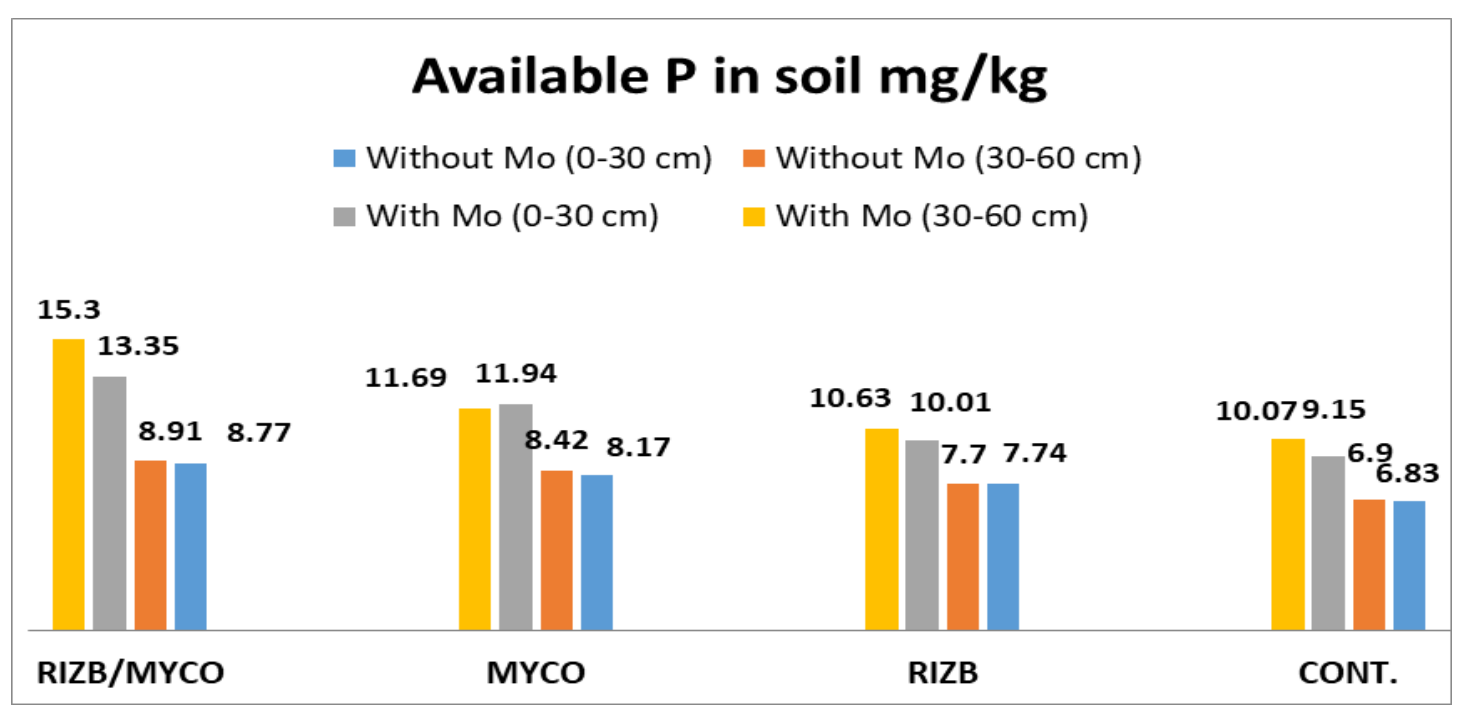

Fig. 2. Available $P$ in soil as influenced by different treatments of biofertilizers without and with Mo foliar application (means of the two successive seasons)

$(10 \mathrm{mg} / \mathrm{kg})$, i.e., $10.01,11.94,13.35 \mathrm{mg} / \mathrm{kg}$ in soils of the upper layer treated with RIZB, MYCO and mixed RIZB/ MYCO, respectively. Thus, using biofertilizer without or with Mo treatment improved available $\mathrm{P}$ in soil (Fig 2).

Available K: Table 2 showed that treatment by RIZB, MYCO and mixed RIZB/ MYCO, without Mo significantly, increased the amount of available $\mathrm{K}$ in soils of the upper layer $(0-30 \mathrm{~cm})$ as compared to the control soil from 42.44 to $59.44,66.35,72.43 \mathrm{mg} / \mathrm{kg}$, respectively. The soils of the upper layer contained significant higher levels of available $\mathrm{K}$ than those of the lower layer.

Foliar application with $5 \mathrm{mg} / \mathrm{l}$ Mo increased significantly the amounts of available $\mathrm{K}$ in soils as compared to the soil did not receive foliar Mo. The amount of available $\mathrm{K}$ in the control soil $(0-30 \mathrm{~cm})$ treated with Mo was significantly higher $(75.49 \mathrm{mg} / \mathrm{kg})$ than in soil did not receive foliar Mo $(42.44 \mathrm{mg} / \mathrm{kg})$. The significant effect of Mo was mostly observed in combination with treatment by biofertilizers. Since the original soil has been contained low level of available $\mathrm{K}$, application of both Mo with mixed RIZB/ MYCO improved the level of available $\mathrm{K}$ in soil. Mean values of available $\mathrm{K}$ in soils were the highest in soils of the upper layer (Fig 3).

The results obtained for available $\mathrm{N}, \mathrm{P}$, and $\mathrm{K}$ presented in Table 2 and Figs 1, 2, and 3 agree with the findings of Ingraffia et al., (2019) who found that AMF symbiosis improved the percentage of $\mathrm{N}$ derived from the atmosphere in the total $\mathrm{N}$ biomass of Faba bean grown in mixture $(+20 \%)$ but not in pure sand. Nitrogen transfered from Faba bean soil to wheat soil was low (2.5-3.0 mg pot $\left.{ }^{-1}\right)$ and inoculation with AMF increased
$\mathrm{N}$ transfer by $20 \%$ in terms of above- and below ground growth and uptake of nutrients. Bargaz et al., (2018) reported that agricultural microorganisms beneficially may also contribute directly or indirectly to crop improvement and fertilizers efficiency. Also, Marzban et al., (2017) found that total concentrations of $\mathrm{N}$ and $\mathrm{P}$ have been enhanced with the use of rhizobium in sole cropping. Thus, the use of Rhizobium and AMF increase the root growth and nutrient uptake by crops.

\section{Organic matter}

Table 3 indicated (as mean values) that there were significant increases in the amounts of $\mathrm{OM}$ in soil did not receive foliar application of $\mathrm{Mo}$ as a result of treatment by MYCO $(0.47 \%)$ and by mixed RIZB/MYCO $(0.50 \%)$ in the upper soil layer $(0-30$ $\mathrm{cm})$. The levels of O.M. were almost higher in soils of the upper layer $(0-30 \mathrm{~cm})$ than in those of the lower layer $(30-60 \mathrm{~cm})$ as compared with the control soil.

Treatment of the soils with RIZB, MYCO or mixed RIZB/MYCO with foliar spray by $5 \mathrm{mg} \mathrm{Mo/l} \mathrm{had}$ increased significantly the amount of OM in the upper soil layer as compared to the control (from 0.53 to 0.58 , from 0.53 to 0.60 , from 0.53 to $0.67 \%$, respectively). Treatment with Mo increased significantly the amount of O.M. in soil since it increased from $0.37 \%$ in the control (without Mo) to $0.53 \%$ in the control (with $\mathrm{Mo}$ ). In the case of treatments by biofertilizers, the increase was from 0.44 to $0.58 \%$ due to RIZB, from 0.47 to $0.63 \%$ for MYCO, and from 0.50 to $0.67 \%$ for mixed RIZB/MYCO, respectively. These data indicate positive significance influence of Mo foliar spray on increasing OM percentage in soils. 


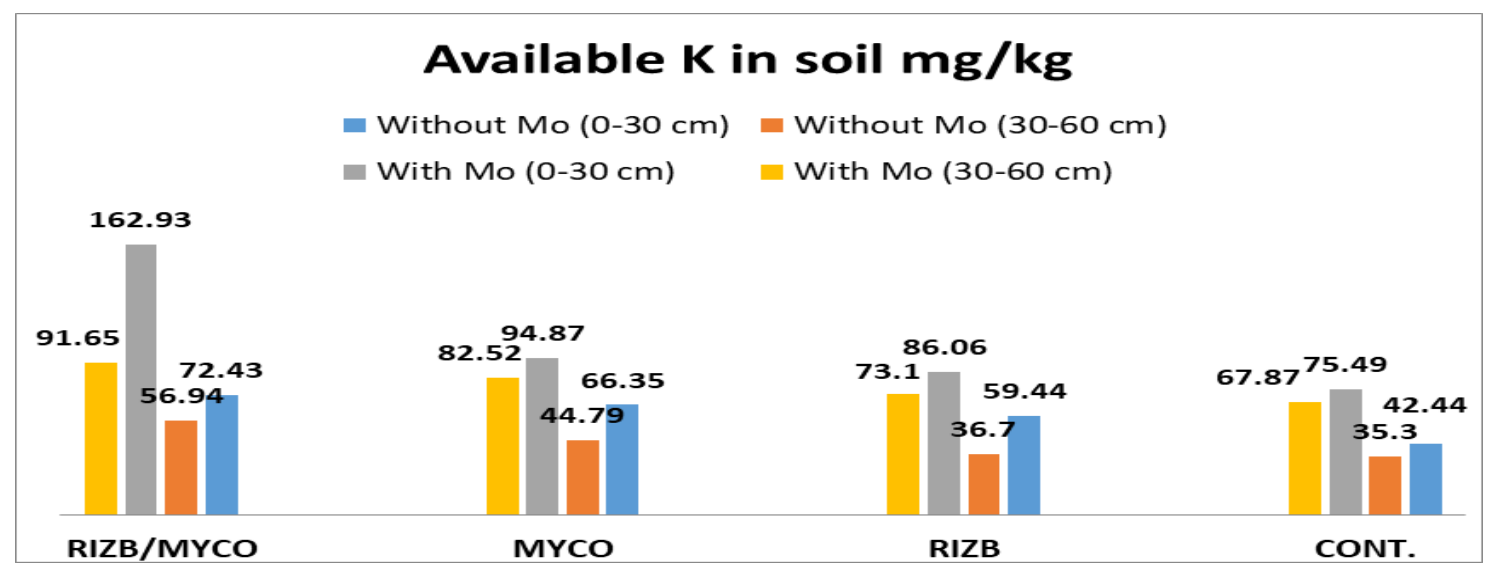

Fig. 3. Available $P$ in soil as influenced by different treatments of biofertilizers without and with Mo foliar application (means of the two successive seasons)

Table 2. The mean value of the amounts of available $N, P$ and $K(\mathrm{mg} / \mathrm{kg})$ in soils collected after plant harvest as influenced by molybdenum and biofertilizers application under drip irrigation system

\begin{tabular}{|c|c|c|c|c|c|c|c|c|c|c|c|}
\hline \multicolumn{2}{|c|}{ Treatments } & \multirow[b]{2}{*}{$\begin{array}{l}\text { Soil depth } \\
\text { (cm) }\end{array}$} & \multicolumn{3}{|c|}{$\mathbf{N}$} & \multicolumn{3}{|c|}{$\mathbf{P}$} & \multicolumn{3}{|c|}{$\mathbf{K}$} \\
\hline $\begin{array}{c}\text { Mo } \\
(\mathrm{mg} / \mathrm{l})\end{array}$ & Bio & & $\begin{array}{l}2016 / \\
2017\end{array}$ & $\begin{array}{c}2017 / 2 \\
018\end{array}$ & Mean & $\begin{array}{c}2016 / 2 \\
017\end{array}$ & $\begin{array}{c}2017 / 2 \\
018\end{array}$ & Mean & $\begin{array}{c}2016 / 2 \\
017\end{array}$ & $\begin{array}{c}2017 / 2 \\
018\end{array}$ & Mean \\
\hline \multirow{8}{*}{0} & \multirow{2}{*}{ CONT. } & $0-30$ & 88.67 & 86.17 & 87.42 & 6.96 & 6.71 & 6.83 & 42.54 & 42.34 & 42.44 \\
\hline & & $30-60$ & 84.47 & 79.93 & 82.20 & 7.00 & 6.81 & 6.90 & 33.97 & 36.64 & 35.30 \\
\hline & \multirow{2}{*}{ RIZB } & $0-30$ & 97.07 & 97.43 & 97.25 & 7.78 & 7.70 & 7.74 & 57.73 & 61.16 & 59.44 \\
\hline & & $30-60$ & 91.70 & 89.87 & 90.78 & 7.89 & 7.52 & 7.70 & 36.31 & 37.15 & 36.70 \\
\hline & \multirow{2}{*}{ MYCO } & $0-30$ & 95.67 & 94.30 & 94.98 & 8.22 & 8.12 & 8.17 & 66.84 & 65.87 & 66.35 \\
\hline & & $30-60$ & 89.90 & 88.07 & 88.98 & 8.51 & 8.33 & 8.42 & 45.57 & 44.01 & 44.79 \\
\hline & \multirow{2}{*}{ MIX } & $0-30$ & 100.80 & 99.17 & 99.98 & 8.81 & 8.73 & 8.77 & 72.92 & 71.95 & 72.43 \\
\hline & & $30-60$ & 95.43 & 96.67 & 96.05 & 9.07 & 8.76 & 8.91 & 57.73 & 56.16 & 56.94 \\
\hline \multirow{2}{*}{\multicolumn{2}{|c|}{ Mean }} & $0-30$ & 95.55 & 94.27 & 94.91 & 7.95 & 7.82 & 7.88 & 60.01 & 60.33 & 60.17 \\
\hline & & $30-60$ & 90.38 & 88.63 & 89.50 & 8.12 & 7.85 & 7.98 & 43.40 & 43.49 & 43.44 \\
\hline \multirow{2}{*}{\multicolumn{2}{|c|}{ CONT. }} & $0-30$ & 105.20 & 105.70 & 105.40 & 9.25 & 9.05 & 9.15 & 75.96 & 75.02 & 75.49 \\
\hline & & $30-60$ & 99.63 & 101.90 & 100.70 & 10.35 & 9.80 & 10.07 & 66.84 & 68.91 & 67.87 \\
\hline \multirow{6}{*}{5} & \multirow{2}{*}{ RIZB } & $0-30$ & 108.80 & 112.00 & 110.40 & 10.11 & 9.91 & 10.01 & 85.07 & 87.06 & 86.06 \\
\hline & & $30-60$ & 108.50 & 110.20 & 109.30 & 10.86 & 10.41 & 10.63 & 72.92 & 73.28 & 73.10 \\
\hline & \multirow{2}{*}{ MYCO } & $0-30$ & 107.40 & 106.50 & 106.90 & 11.93 & 11.95 & 11.94 & 94.19 & 95.55 & 94.87 \\
\hline & & $30-60$ & 107.80 & 107.50 & 107.60 & 11.87 & 11.52 & 11.69 & 82.03 & 83.02 & 82.52 \\
\hline & \multirow{2}{*}{ MIX } & $0-30$ & 116.50 & 117.00 & 116.70 & 12.85 & 13.85 & 13.35 & 157.9 & 167.8 & 162.93 \\
\hline & & $30-60$ & 120.90 & 120.80 & 120.90 & 15.69 & 14.92 & 15.30 & 91.48 & 91.82 & 91.65 \\
\hline \multirow{2}{*}{\multicolumn{2}{|c|}{ Mean }} & $0-30$ & 109.50 & 110.30 & 109.90 & 11.03 & 11.19 & 11.11 & 103.30 & 106.40 & 104.84 \\
\hline & & $30-60$ & 109.20 & 110.10 & 109.60 & 12.19 & 11.66 & 11.92 & 78.32 & 79.26 & 78.79 \\
\hline \multirow{4}{*}{$\begin{array}{l}\text { LSD } \\
0.05\end{array}$} & \multirow{2}{*}{ Mo } & $0-30$ & 5.08 & 3.99 & 4.54 & 0.59 & 0.34 & 0.46 & 7.24 & 7.70 & 7.47 \\
\hline & & $30-60$ & 5.20 & 3.34 & 4.27 & 0.84 & 0.75 & 0.79 & 3.96 & 4.55 & 4.25 \\
\hline & \multirow{2}{*}{ Bio } & $0-30$ & 7.18 & 5.64 & 6.41 & 0.84 & 0.48 & 0.66 & 10.25 & 10.89 & 10.57 \\
\hline & & $30-60$ & 7.36 & 4.73 & 6.05 & 1.19 & 1.07 & 1.13 & 5.61 & 6.43 & 6.02 \\
\hline
\end{tabular}

\section{Soil respiration}

Application of RIZB, MYCO or mixed RIZB/MYCO without Mo foliar spray increased significantly the level of soil respiration from a mean value of $17.6 \mathrm{mg} \mathrm{CO} / 100 \mathrm{~g}$ in soil of the upper layer (the control soil) to $23.22,25.90,35.41 \mathrm{mg} \mathrm{CO} / 100 \mathrm{~g}$ 
soil due to treatment by RIZB, MYCO or mixed RIZB/MYCO, respectively (Table 3). The same effect was obtained without Mo treatment. The level of soil respiration was almost higher in soil of the upper layer $(0-30 \mathrm{~cm})$ than in those of the lower layer $(30-60 \mathrm{~cm})$. Foliar application by $5 \mathrm{mg} \mathrm{Mo} / \mathrm{l}$ significantly increased the level of soil respiration in the control soil of the upper layer $(0-30 \mathrm{~cm}$ ) from 17.60 to $43.44 \mathrm{mg}$ $\mathrm{CO} 2 / 100 \mathrm{~g}$ soil from 23.22 to 47.22 , from 25.90 to 54.25 from 33.41 to $69.03 \mathrm{mg} \mathrm{CO} 2 / 100 \mathrm{~g}$ soil due to RIZB, MYCO or mixed RIZB/MYCO treatment, respectively. These data indicate the significantly effect of Mo for increasing soil respiration as compared to the lack of Mo (Table 3). These findings agree with those found by Dubova et al., (2018) who estimated the microbiological activity of the soil in different bean sowings. In reduced tillage, there was consistently less microbial respiration under continuous cereal cover than under Faba bean.

\section{1. plant}

\section{NPK contents in leaves}

$\mathbf{N}$ content: Table 4 showed significant increase in $\mathbf{N}$ contents of leaves of Faba bean plant grown in the absence of foliar application by Mo as a result of RIZB, MYCO and mixed RIZB/MYCO treatments. The highest $\mathrm{N}$ content $(1.43 \%)$ was due to mixed RIZB/MYCO biofertilizer application and the lowest $(1.03 \%)$ was due to RIZB treatment as compared to the control $(0.72 \%)$.

The concentration of $\mathrm{N}$ in leaves of plants grown with foliar application by Mo significantly increased as a result of biofertilizer treatment and was $1.14 \%$ for RIZB, $0.98 \%$ for MYCO and $1.79 \%$ for mixed RIZB/MYCO treatment. Application of $5 \mathrm{mg} \mathrm{Mo/l}$ increased significantly $\mathrm{N}$ percentage in plant leaves with a mean value of $1.17 \%$ as compared with leaves of plants grown in the absence of application of Mo with a mean value of $1.01 \%$, due to all biofertilizer treatments.

Table 3. Soil respiration and organic matter in soil collected after plant harvest as influenced by molybdenum and biofertilizers application under drip irrigation system in the two growing seasons

\begin{tabular}{|c|c|c|c|c|c|c|c|c|}
\hline \multicolumn{2}{|c|}{ Treatments } & \multirow{2}{*}{$\begin{array}{c}\text { Soil } \\
\text { depth } \\
(\mathrm{cm})\end{array}$} & \multicolumn{3}{|c|}{$\begin{array}{c}\text { Soil respiration } \\
(\mathrm{mg} \mathrm{CO} / 100 \mathrm{~g} \text { soil })\end{array}$} & \multicolumn{3}{|c|}{ OM (\%) } \\
\hline Mo (mg/l) & Bio & & $2016 / 2017$ & $2017 / 2018$ & Mean & $2016 / 2017$ & $2017 / 2018$ & Mean \\
\hline \multirow{8}{*}{0} & \multirow[t]{2}{*}{ CONT. } & $0-30$ & 5.22 & 29.98 & 17.6 & 0.37 & 0.36 & 0.37 \\
\hline & & $30-60$ & 21.09 & 4.84 & 12.96 & 0.29 & 0.31 & 0.30 \\
\hline & \multirow[t]{2}{*}{ RIZB } & $0-30$ & 11.71 & 34.73 & 23.22 & 0.45 & 0.43 & 0.44 \\
\hline & & $30-60$ & 27.57 & 4.84 & 16.20 & 0.37 & 0.38 & 0.38 \\
\hline & \multirow[t]{2}{*}{ MYCO } & $0-30$ & 11.71 & 40.09 & 25.9 & 0.47 & 0.47 & 0.47 \\
\hline & & $30-60$ & 35.20 & 4.90 & 20.05 & 0.44 & 0.45 & 0.45 \\
\hline & \multirow[t]{2}{*}{ MIX } & $0-30$ & 16.82 & 54.01 & 35.41 & 0.50 & 0.50 & 0.50 \\
\hline & & $30-60$ & 49.16 & 9.83 & 29.49 & 0.47 & 0.47 & 0.47 \\
\hline \multirow{2}{*}{\multicolumn{2}{|c|}{ Mean }} & $0-30$ & 11.06 & 39.70 & 25.38 & 0.45 & 0.44 & 0.45 \\
\hline & & $30-60$ & 33.25 & 5.94 & 19.59 & 0.39 & 0.40 & 0.40 \\
\hline \multirow{8}{*}{5} & \multirow[t]{2}{*}{ CONT. } & $0-30$ & 23.34 & 63.54 & 43.44 & 0.52 & 0.53 & 0.53 \\
\hline & & $30-60$ & 58.66 & 15.19 & 36.92 & 0.49 & 0.49 & 0.49 \\
\hline & \multirow[t]{2}{*}{ RIZB } & $0-30$ & 24.73 & 70.72 & 47.72 & 0.57 & 0.58 & 0.58 \\
\hline & & $30-60$ & 65.87 & 16.67 & 41.27 & 0.51 & 0.51 & 0.51 \\
\hline & \multirow[t]{2}{*}{ MYCO } & $0-30$ & 28.45 & 80.05 & 54.25 & 0.62 & 0.63 & 0.63 \\
\hline & & $30-60$ & 75.19 & 20.36 & 47.77 & 0.53 & 0.55 & 0.54 \\
\hline & \multirow[t]{2}{*}{ MIX } & $0-30$ & 37.60 & 100.5 & 69.03 & 0.66 & 0.68 & 0.67 \\
\hline & & $30-60$ & 95.56 & 24.35 & 59.95 & 0.61 & 0.62 & 0.615 \\
\hline \multirow{2}{*}{\multicolumn{2}{|c|}{ Mean }} & $0-30$ & 28.53 & 78.69 & 53.61 & 0.60 & 0.60 & 0.60 \\
\hline & & $30-60$ & 73.82 & 19.14 & 46.48 & 0.54 & 0.54 & 0.54 \\
\hline \multirow{4}{*}{ LSD 0.05} & \multirow[t]{2}{*}{ Mo } & $0-30$ & 2.47 & 7.04 & 4.75 & 0.03 & 0.02 & 0.02 \\
\hline & & $30-60$ & 4.09 & 1.88 & 2.98 & 0.041 & 0.02 & 0.030 \\
\hline & \multirow[t]{2}{*}{ Bio } & $0-30$ & 3.50 & 7.04 & 5.27 & 0.05 & 0.02 & 0.03 \\
\hline & & $30-60$ & 5.78 & 2.66 & 4.22 & 0.058 & 0.03 & 0.04 \\
\hline
\end{tabular}


P content: Leaves of plants grown without Mo application contained (as a mean value) high levels of $\mathrm{P}$ as compared to the control as a result of biofertilizer treatments (Table 4). The highest P content $(0.42 \%)$ was a result of mixed RIZB/MYCO treatment and the lowest $(0.25 \%)$ was due to RIZB treatment. Leaves of plants grown with Mo application contained (as a mean value) significantly higher $\mathrm{P}$ content than the control as a result of biofertilizer treatments. The highest $\mathrm{P}$ percentage $(0.59 \%)$ was due to mixed RIZB/MYCO treatment and the lowest $(0.36 \%)$ was due to RIZB treatment as compared to the control $(0.32 \%)$.

The obtained results indicated that Mo $(5 \mathrm{mg} / \mathrm{l})$ foliar application has improved plant performance to take up $\mathrm{P}$ from soil whether in the presence or absence of biofertilizer. The mean value of $\mathrm{P}$ percentage due to addition of Mo was $0.43 \%$ and without addition of Mo was $0.29 \%$ (Table 4).

K content: the data depicted in Table 4 showed that there were significant increases in $\mathrm{K}$ contents in leaves of plants grown without Mo application as a result of each biofertilizer treatment compared to the control treatment. The highest $\mathrm{K}$ content in plant leaves $(0.25$ $\%)$ was due to mixed RIZB/MYCO treatment and the lowest $(0.18 \%)$ was due to RIZB treatment as compared to the control $(0.16 \%)$. The leaves of plants grown with Mo foliar application contained significant higher levels of $\mathrm{K}$ percentage as compared to those grown without Mo application with each biofertilizer treatments (Table 4). The highest value $(0.59 \%)$ was a result of mixed RIZB/MYCO treatment and the lowest $(0.25 \%)$ was due to RIZB treatment as compared to the control $(0.21 \%)$. Foliar application of Mo $(5 \mathrm{mg} / \mathrm{l})$ stimulated $\mathrm{K}$ increase in leaves of plants whether in the presence or absence of biofertilizer additions. This indicates the significant stimulating effect of Mo for increasing $\mathrm{K}$ in plant leaves.

The concentrations of NPK in leaves are in accordance with those obtained by Badr et al., (2013) who concluded that the inoculation with VAmycorrhizal fungi led to highly significant increases in $\mathrm{N}$ and $\mathrm{P}$ contents in leaves of Faba bean, it was also found that mycorrhiza inoculation significantly increased the macronutrients of $\mathrm{N}, \mathrm{P}$ and $\mathrm{K}$ in plant. Khatab., 2016 and Vafadar et al., 2014 also Raklami et al., (2019) showed that the inoculation with PGPRrhizobia-mycorrhizae improved $\mathrm{N}, \mathrm{P}$ and $\mathrm{K}$ levels in shoot, as well as the contents of proteins. The positive influence of the tested biofertilizers suggests an interest of adoption of innovative practices that improving crop productivity and soil fertility.

\section{NPK content in grains}

Nitrogen: Table 5 showed significant increase in $\mathrm{N}$ content in grains of Faba bean plant grown without Mo treatment as a result of treatment by RIZB, MYCO or RIZB/MYCO with mean values of $4.14,3.71$ and 4.37 $\%$, respectively as compared to the control (mean value of $3.43 \%$ ). The grains of plants grown with Motreatment, the $\mathrm{N}$ percentage increased by biofertilizer application as compared to the control with mean value of 4.20, 4.03, $4.46 \%$ as compared to the control (3.24 $\%)$ due to RIZB, MYCO and mixed RIZB/MYCO treatments, respectively (Table 5). It is also clear from Table 5 that $\mathrm{N}$ contents in grains of plant grown with Mo was higher (mean value of $4.06 \%$ ) than in those grown without Mo treatment soil (mean value of $3.91 \%$ ).

Phosphorus: The $\mathrm{P}$ contents (Table 5) in grains of plants grown without Mo significantly increased as a result of biofertilizer treatments with mean values of $0.24,0.26,0.30 \%$ due to RIZB, MYCO and mixed RIZB/MYCO treatments, respectively, as compared to the control $(0.21 \%)$. The $\mathrm{P}$ contents in grains of plants grown with Mo treatment were higher than in those grown without Mo treatment (Table 5). It is also clear that $\mathrm{P}$ contents in the grains significantly increased as a result of RIZB treatment (mean value of $0.26 \%$ ), MYCO treatment (mean value of $0.27 \%$ ) and mixed RIZB/MYCO treatment (mean value of $0.31 \%$ ). Thus, foliar spraying $5 \mathrm{mg} \mathrm{Mo} / \mathrm{l}$ in combination with biofertilizer produced higher $\mathrm{P}$ contents in grains with mean value of $0.27 \%$ than in those of plants grown without foliar application of Mo $(0.25 \%)$.

Potassium: Table 5 showed that RIZB, MYCO and mixed RIZB/MYCO treatments significantly increased $\mathrm{K}$ contents in the grains of plants grown without Mo treatment. The highest value was $(1.23 \%)$ this due to mixed RIZB/MYCO treatment and the lowest was $(1.16 \%)$ due to the treatment by RIZB, as compared to the control (mean value of $1.13 \%$ ).

Grains of plants grown with Mo foliar application contained high levels of $\mathrm{K}$ with mean value of 1.24, $1.26,1.28 \%$ for RIZB, MYCO and mixed RIZB/MYCO treatment, respectively as compared to the control $(1.19 \%)$. It is clear that on the basis of the average all mean values of $\mathrm{K}$ contents in grains of plants grown with Mo application and with all biofertilizer treatments the $\mathrm{K}$ content was higher (1.25 $\%)$ than in those of plants grown without Mo application for all biofertilizer treatments. 


\section{Protein content in grains}

Table 5 showed that there is significant increase in protein content in the grains of Faba bean plant grown without Mo treatment as a result of RIZB, MYCO or mix RIZB/MYCO treatments. The highest mean value was $27.29 \%$ due to mix RIZB/MYCO treatment and the lowest was $23.22 \%$ due to MYCO treatment as compared to the control treatment $(21.46 \%)$.

Grains of plants grown with Mo foliar application contained higher protein percentage as a result of Mo addition $(5 \mathrm{mg} / \mathrm{l})$ and also to application of RIZB, MYCO and mix RIZB/MYCO. However, there were no significant variations between protein contents in the grain of plants grown with Mo-treatment and without Mo-untreatment which indicates that Mo addition has no significant effect on the level of protein in the grains of Faba bean, and that the variations are related only to the different biofertilizer treatments (Table 5 and Fig 4). These findings agree with those found by Khatab, (2016) who found that mycorrhiza fungi inoculation significantly affected $\mathrm{N}, \mathrm{P}$ and $\mathrm{K}$ contents in seeds. Also, Khalil et al., (2014) stated that mycorrhiza inoculation increased protein and minerals contents compared with non-inoculated plants. Kandil et al., (2013) observed that protein content was produced as a result of Mo foliar application to common bean.
Mandou et al., (2017) elicited that the significant highest seed $\mathrm{N}$ content was obtained by combining rhizobium with Mo application.

\section{Vegetative growth characters}

Plant weight: Table 6 showed a significant increase in the fresh weight of plants (as mean value) without MO foliar application as influenced by RIZB (72.00 gram/plant), MYCO (82.22 $\mathrm{g} /$ plant $)$ and mix RIZB/MYCO (95.78 g/plant) as compared with the control $(61.72 \mathrm{~g} / \mathrm{plant})$. The plants grown with foliar spray by Mo and biofertilizer treatment significantly increased plant weight with all biofertilizers treatments. It is clear, therefore, that Mo treatments increased significantly plant weight as compared to those grown without Mo foliar spray.

Plant height: The height of Faba bean plant significantly increased as a result of treatment by RIZB, MYCO and mixed RIZB/MYCO biofertilizr whether plants grown without Mo or with Mo foliar application (Table 6). As mean value, treatment by mixed RIZB/MYCO produced lower plant height without Mo application $(131.8 \mathrm{~cm})$ than those grown with Mo application $(148.1 \mathrm{~cm})$. This indicated significant positive effect of Mo as stimulating plant growth. i.e., the overall mean plant height was 118.2 $\mathrm{cm}$ without Mo and was $137.4 \mathrm{~cm}$ with Mo treatment.

Table 4. The contents of $\mathbf{N}, \mathbf{P}$ and $\mathrm{K}(\%)$ in leaves of Faba bean plant grown under drip irrigation as influenced by biofertilizers in the absence and presence of Mo application in the two growing seasons

\begin{tabular}{|c|c|c|c|c|c|c|c|c|c|c|}
\hline \multirow{2}{*}{\multicolumn{2}{|c|}{ Treatments }} & \multicolumn{3}{|c|}{$\mathbf{N}$} & \multicolumn{3}{|c|}{$\mathbf{P}$} & \multicolumn{3}{|c|}{$\mathbf{K}$} \\
\hline & & \multirow{2}{*}{$\begin{array}{l}2016 / \\
2017\end{array}$} & \multirow{2}{*}{$\begin{array}{l}2017 / \\
2018\end{array}$} & \multirow{2}{*}{ Mean } & \multirow{2}{*}{$\begin{array}{l}2016 / \\
2017\end{array}$} & \multirow{2}{*}{$\begin{array}{l}2017 / \\
2018\end{array}$} & \multirow{2}{*}{ Mean } & \multirow{2}{*}{$\begin{array}{l}2016 / \\
2017\end{array}$} & \multirow{2}{*}{$\begin{array}{l}2017 / \\
2018\end{array}$} & \multirow{2}{*}{ Mean } \\
\hline Mo mg/l & Bio & & & & & & & & & \\
\hline \multirow{4}{*}{0} & CONT. & 0.71 & 0.73 & 0.72 & 0.18 & 0.18 & 0.18 & 0.15 & 0.17 & 0.16 \\
\hline & RIZB & 1.01 & 1.05 & 1.03 & 0.25 & 0.26 & 0.25 & 0.18 & 0.18 & 0.18 \\
\hline & MYCO & 0.86 & 0.89 & 0.87 & 0.33 & 0.34 & 0.33 & 0.21 & 0.22 & 0.22 \\
\hline & MIX & 1.41 & 1.45 & 1.43 & 0.42 & 0.42 & 0.42 & 0.25 & 0.26 & 0.26 \\
\hline \multicolumn{2}{|c|}{ Mean } & 1.00 & 1.03 & 1.01 & 0.29 & 0.30 & 0.29 & 0.20 & 0.21 & 0.20 \\
\hline \multirow{4}{*}{5} & CONT. & 0.79 & 0.81 & 0.80 & 0.32 & 0.32 & 0.32 & 0.21 & 0.22 & 0.21 \\
\hline & RIZB & 1.14 & 1.15 & 1.14 & 0.36 & 0.36 & 0.36 & 0.25 & 0.26 & 0.25 \\
\hline & MYCO & 0.95 & 1.01 & 0.98 & 0.44 & 0.45 & 0.44 & 0.28 & 0.29 & 0.28 \\
\hline & MIX & 1.70 & 1.88 & 1.79 & 0.59 & 0.60 & 0.59 & 0.56 & 0.63 & 0.59 \\
\hline \multicolumn{2}{|c|}{ Mean } & 1.14 & 1.21 & 1.17 & 0.43 & 0.43 & 0.43 & 0.32 & 0.35 & 0.33 \\
\hline \multirow{2}{*}{ LSD 0.05} & Mo & 0.07 & 0.08 & 0.07 & 0.01 & 0.01 & 0.01 & 0.02 & 0.04 & 0.03 \\
\hline & Bio & 0.10 & 0.11 & 0.10 & 0.02 & 0.01 & 0.01 & 0.03 & 0.06 & 0.04 \\
\hline
\end{tabular}


Table 5. The contents of NPK and protein (\%) in grains of Faba bean plant grown under drip irrigation as influenced by biofertilizers in the absence and presence of Mo application in the two growing seasons

\begin{tabular}{|c|c|c|c|c|c|c|c|c|c|c|c|c|c|}
\hline \multicolumn{2}{|c|}{ Treatments } & \multicolumn{3}{|c|}{$\mathbf{N}$} & \multicolumn{3}{|c|}{$\mathbf{P}$} & \multicolumn{3}{|c|}{$\mathbf{K}$} & \multicolumn{3}{|c|}{ Protein } \\
\hline & & \multirow{2}{*}{$\begin{array}{l}2016 / \\
2017\end{array}$} & \multirow{2}{*}{$\begin{array}{c}2017 / \\
2018\end{array}$} & \multirow{2}{*}{$\begin{array}{c}\text { Mea } \\
\mathbf{n}\end{array}$} & \multirow{2}{*}{$\begin{array}{l}2016 / \\
2017\end{array}$} & \multirow{2}{*}{$\begin{array}{l}2017 / \\
2018\end{array}$} & \multirow[t]{2}{*}{ Mean } & \multirow{2}{*}{$\begin{array}{l}2016 / \\
2017\end{array}$} & \multirow{2}{*}{$\begin{array}{l}2017 / \\
2018\end{array}$} & \multirow[t]{2}{*}{ Mean } & \multirow{2}{*}{$\begin{array}{l}2016 / \\
2017\end{array}$} & \multirow{2}{*}{$\begin{array}{l}2017 / \\
2018\end{array}$} & \multirow[t]{2}{*}{ Mean } \\
\hline Mo mg/l & Bio & & & & & & & & & & & & \\
\hline \multirow{4}{*}{0} & CONT. & 3.33 & 3.54 & 3.43 & 0.21 & 0.22 & 0.21 & 1.13 & 1.13 & 1.13 & 20.81 & 22.12 & 21.46 \\
\hline & RIZB & 4.14 & 4.14 & 4.14 & 0.24 & 0.25 & 0.24 & 1.15 & 1.17 & 1.16 & 25.89 & 25.90 & 25.89 \\
\hline & MYCO & 3.71 & 3.72 & 3.71 & 0.26 & 0.26 & 0.26 & 1.19 & 1.20 & 1.19 & 23.21 & 23.23 & 23.22 \\
\hline & MIX & 4.35 & 4.39 & 4.37 & 0.30 & 0.31 & 0.30 & 1.23 & 1.23 & 1.23 & 27.17 & 27.41 & 27.29 \\
\hline \multicolumn{2}{|c|}{ Mean } & 3.88 & 3.95 & 3.91 & 0.25 & 0.26 & 0.25 & 1.18 & 1.18 & 1.18 & 24.27 & 24.66 & 24.46 \\
\hline \multirow{4}{*}{5} & CONT. & 3.41 & 3.68 & 3.54 & 0.24 & 0.25 & 0.24 & 1.19 & 1.20 & 1.19 & 21.31 & 23.01 & 22.16 \\
\hline & RIZB & 4.18 & 4.22 & 4.20 & 0.26 & 0.26 & 0.26 & 1.24 & 1.25 & 1.24 & 26.17 & 26.38 & 26.27 \\
\hline & MYCO & 4.03 & 4.04 & 4.03 & 0.27 & 0.28 & 0.27 & 1.26 & 1.27 & 1.26 & 25.17 & 25.23 & 25.2 \\
\hline & MIX & 4.43 & 4.49 & 4.46 & 0.31 & 0.32 & 0.31 & 1.28 & 1.29 & 1.28 & 27.66 & 28.07 & 27.86 \\
\hline \multicolumn{2}{|c|}{ Mean } & 4.01 & 4.11 & 4.06 & 0.27 & 0.28 & 0.27 & 1.25 & 1.25 & 1.25 & 25.08 & 25.68 & 25.38 \\
\hline \multirow{2}{*}{ LSD 0.05} & Mo & 0.33 & 0.22 & 0.27 & 0.03 & 0.01 & 0.02 & 0.04 & 0.06 & 0.05 & 2.05 & 1.40 & 1.72 \\
\hline & Bio & 0.46 & 0.32 & 0.39 & 0.04 & 0.01 & 0.025 & 0.06 & 0.08 & 0.07 & 2.90 & 1.98 & 2.44 \\
\hline
\end{tabular}

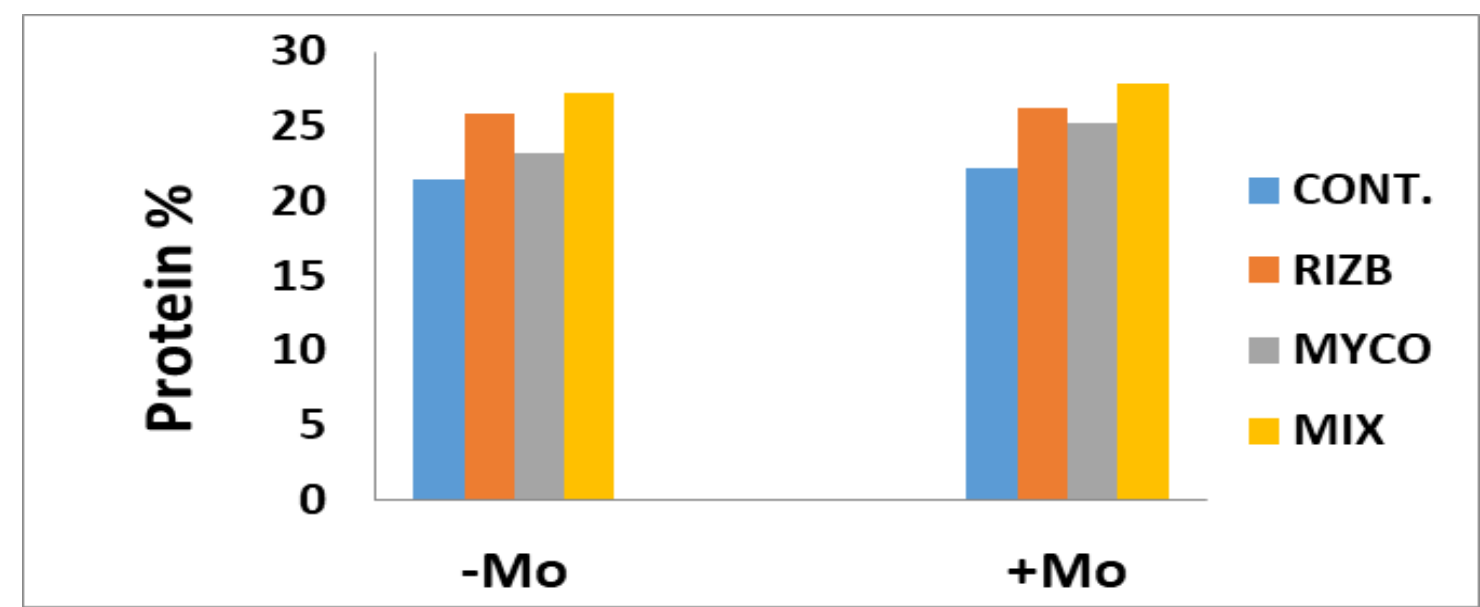

Fig. 4. Protein in the grains of Faba bean as influenced by different treatments of biofertilizers without and with Mo application (mean of two successive seasons)

Roots weight: Table 6 showed significant increase in roots weight of plants grown without Mo treatment or with Mo as a result of treatment by RIZB, MYCO or mixed RIZB/MYCO. It is clear that mixed $\mathrm{RIZB} / \mathrm{MYCO}$ treatment produced the highest roots weight of plants grown whether without Mo (38.87 $\mathrm{g} /$ plant) or with Mo $(53.31 \mathrm{~g} / \mathrm{plant})$ treatment. Thus, the inter combinations between biofertilizer and Mo treatments have significant stimulating effect on roots weight and consequently plant growth.

Root length: Table 6 showed that application of RIZB, MYCO or mixed RIZB/MYCO without Mo application significantly increased root length. The highest value of root length was due to mixed RIZB/MYCO (mean value of $24.5 \mathrm{~cm}$ ). For plants grown with Mo foliar spray, the highest value of root length $(28.3 \mathrm{~cm})$ was due to treatment by mixed RIZB/MYCO. The overall mean value of root length for plants grown without Mo was $22.0 \mathrm{~cm}$ and that grown with Mo was $25.8 \mathrm{~cm}$. These data indicate the significant effect of application of biofertilizer in combination with foliar application by Mo in improving root length and consequently plant growth.

These findings agree with those reported by Badr et al., (2013) who found that inoculation with VAmycorrhizal fungi led to highly significant increases in plant height and number of branches. Khatab (2016) showed that mycorrhiza inoculation significantly affected growth characters i.e. plant height and branches number/ plant. Also, Vafadar et al., (2014) 
suggested that mycorrhiza fungi significantly increased root and shoot biomass of plants. Ingraffia et al., (2019) found that root colonisation by AMF was greater in Faba bean than in wheat and that Mycorrhizal symbiosis positively influenced root biomass, root length, and root density.

\section{Yield components}

The number of branches per plant grown without Mo foliar spray significantly increased by application of RIZB, MYCO or mixed RIZB/MYCO, with an overall mean value of 5.0 branches /plant (Table7). Plants grown with Mo application and treated by each biofertilizer showed higher numbers of branches (an overall mean value of 6.7 branches /plant).

Table (7) showed significant increases in the number of pods/plant when Faba bean was grown without Mo or with Mo treatment as a result of biofertilizer application. The highest number of pods/plant was produced with Mo foliar application (an overall mean value of 20.5 pods/plant) as compared to that produced without Mo foliar application (an overall value of 15.9 pods/plant).

The weight of 100 grains of Faba bean increased significantly as a result of application of RIZB, MYCO or mixed RIZB/MYCO whether plants are grown without Mo or with Mo application (Table 7). The overall mean value of the weight of 100 grains was $86.88 \mathrm{~g}$ and $100.69 \mathrm{~g}$ for plants grown without Mo and with Mo application, respectively.

The total grain weight per plant behaved in similar trend with over all mean values of $63.68 \mathrm{~g} / \mathrm{plant}$ and $82.21 \mathrm{~g} /$ plant for plants grown without Mo and with Mo application, respectively (Table 7).
The grain yield of Faba bean followed similar trends as with weight of 100 grains and total grain weight per plant. As an overall mean value, the grain yield produced from plants grown without Mo was $3.65 \mathrm{t} / \mathrm{ha}$ and from those grown with Mo application was 4.72 t/ha. These results indicate significant stimulating effects of the combination treatments by biofertilizers (RIZB, MYCO or mixed RIZB/MYCO) and Mo foliar spray for increasing growth and crop yield of Faba bean grown in sandy soil. Also, Fig. (5) showed that the highest value of grain yield was obtained as a result of treatment by mix RIZB/MYCO then by MYCO followed by RIZB without Mo or with Mo treatments.

The obtained results in Table 7 are in harmony with those obtained by Badr et al., (2013) who found that the number of pods, seeds/ plant, 100-seed weight and seed yield/ha of Faba bean cultivars treated with VA-mycorrhizal was increased by $20.7 \%$ and $23.2 \%$ more than the non-inoculated treatment. Khatab (2016) showed that yield of Faba bean significantly affected by mycorrhiza inoculation. Kandil et al., (2013) observed that the highest number of pods/ plant was produced when Mo was foliar applied to common bean. El-Wakeil and El-Sebai (2007) found that mixed inoculants strains showed positive effect on Faba bean seeds weight compared to NPK fertilizer and the highest number of pods was achieved in treatment of rhizobia mixed with mycorrhiza. Mandou et al., (2017) found that Molybdenum application and rhizobia inoculation had a significant effect on yield of peanut. Raklami et al., (2019) and Crusciol et al., (2019) found that the inoculation improved the productivity of the number and weight of bean pods.

Table 6. Vegetative growth characters of Faba bean plant grown under drip irrigation as influenced by biofertilizers in the absence and presence of Mo application in the two growing seasons

\begin{tabular}{|c|c|c|c|c|c|c|c|c|c|c|c|c|c|}
\hline \multicolumn{2}{|c|}{ Treatments } & \multicolumn{3}{|c|}{ Plant wt. (g) } & \multicolumn{3}{|c|}{ Plant height (cm) } & \multicolumn{3}{|c|}{ Roots wt. (g/plant) } & \multicolumn{3}{|c|}{ Root Length (cm) } \\
\hline $\begin{array}{c}\mathrm{Mo}(\mathrm{mg} / \mathrm{l} \\
)\end{array}$ & Bio & $\begin{array}{l}2016 / \\
2017\end{array}$ & $\begin{array}{c}2017 / \\
2018\end{array}$ & Mean & $\begin{array}{l}2016 / \\
2017\end{array}$ & $\begin{array}{l}2017 / \\
2018\end{array}$ & Mean & $\begin{array}{l}2016 / \\
2017\end{array}$ & $\begin{array}{c}2017 / \\
2018\end{array}$ & Mean & $\begin{array}{l}2016 / \\
2017\end{array}$ & $\begin{array}{c}2017 / \\
2018\end{array}$ & Mean \\
\hline \multirow{4}{*}{0} & CONT. & 61.22 & 62.22 & 61.72 & 107.0 & 106.3 & 106.6 & 21.37 & 22.63 & 22.0 & 18.6 & 18.3 & 18.5 \\
\hline & RIZB & 71.44 & 72.56 & 72.00 & 113.0 & 114.0 & 113.5 & 24.67 & 25.90 & 25.28 & 21.6 & 22.0 & 21.8 \\
\hline & MYCO & 80.56 & 83.89 & 82.22 & 120.0 & 121.6 & 120.8 & 30.17 & 31.40 & 30.78 & 23.3 & 23.0 & 23.2 \\
\hline & MIX & 94.67 & 96.89 & 95.78 & 129.6 & 134.0 & 131.8 & 38.87 & 38.87 & 38.87 & 24.3 & 24.6 & 24.5 \\
\hline & ean & 76.97 & 78.89 & 77.93 & 117.4 & 119.0 & 118.2 & 28.77 & 29.70 & 29.23 & 22.0 & 22.0 & 22.0 \\
\hline \multirow{4}{*}{5} & CONT. & 88.00 & 91.33 & 89.66 & 126.6 & 128.0 & 127.3 & 31.33 & 32.73 & 32.03 & 23.6 & 23.0 & 23.3 \\
\hline & RIZB & 98.67 & 99.78 & 99.22 & 134.6 & 132.6 & 133.6 & 38.90 & 40.57 & 39.73 & 25.0 & 25.0 & 25.0 \\
\hline & MYCO & 119.4 & 120.1 & 119.7 & 139.0 & 142.3 & 140.6 & 43.87 & 44.87 & 44.37 & 26.3 & 27.0 & 26.7 \\
\hline & MIX & 145.1 & 148.4 & 146.7 & 147.3 & 149.0 & 148.1 & 53.00 & 53.63 & 53.31 & 28.3 & 28.3 & 28.3 \\
\hline \multicolumn{2}{|c|}{ Mean } & 112.8 & 114.9 & 113.8 & 136.9 & 138.0 & 137.4 & 41.78 & 42.95 & 42.36 & 25.8 & 25.8 & 25.8 \\
\hline LSD & Mo & 3.25 & 4.30 & 3.77 & 2.52 & 3.14 & 2.83 & 1.63 & 1.92 & 1.775 & 0.3 & 1.1 & 0.68 \\
\hline 0.05 & Bio & 4.59 & 6.08 & 5.33 & 3.56 & 4.44 & 4.00 & 2.30 & 2.71 & 2.505 & 0.4 & 1.5 & 0.97 \\
\hline
\end{tabular}




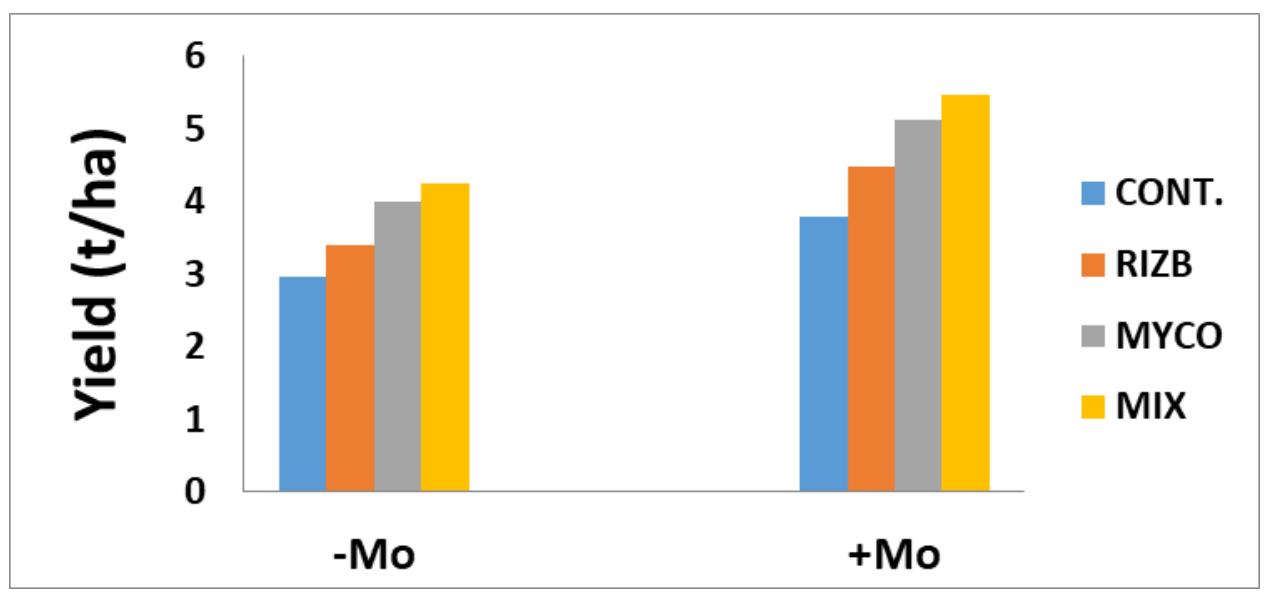

Fig.5. Yield of Faba bean as influenced by different treatments of biofertilizers without and with Mo application (mean of two successive seasons)

Table 7. Yield components of Faba bean grown under drip irrigation as influenced by biofertilizers without and with Mo application in the two growing seasons

\begin{tabular}{|c|c|c|c|c|c|c|c|c|c|c|c|c|c|c|c|c|}
\hline \multicolumn{2}{|c|}{ Treatments } & \multicolumn{3}{|c|}{$\begin{array}{c}\text { No. of branches/ } \\
\text { plant }\end{array}$} & \multicolumn{3}{|c|}{ No. of Pods /plant } & \multicolumn{3}{|c|}{100 grain wt. (g) } & \multicolumn{3}{|c|}{$\begin{array}{c}\text { total grain wt. } \\
\text { (g/plant) }\end{array}$} & \multicolumn{3}{|c|}{ Grain Yield (t/ha) } \\
\hline $\begin{array}{l}\text { Mo } \\
\mathrm{mg} / \mathrm{l}\end{array}$ & Bio & $\begin{array}{r}2016 / \\
2017\end{array}$ & $\begin{array}{r}2017 / \\
2018\end{array}$ & Mean & $\begin{array}{l}2016 / \\
2017\end{array}$ & $\begin{array}{l}2017 / \\
2018\end{array}$ & Mean & $\begin{array}{l}2016 / \\
2017\end{array}$ & $\begin{array}{c}2017 / \\
2018\end{array}$ & Mean & $\begin{array}{l}2016 / \\
2017\end{array}$ & $\begin{array}{l}2017 / \\
2018\end{array}$ & Mean & $\begin{array}{l}2016 / \\
2017\end{array}$ & $\begin{array}{l}2017 / \\
2018\end{array}$ & Mean \\
\hline \multirow{3}{*}{0} & CONT. & 3.91 & 4.09 & 4.0 & 13.47 & 12.78 & 13.1 & 77.13 & 77.13 & 77.13 & 53.87 & 51.11 & 52.49 & 3.10 & 2.80 & 2.95 \\
\hline & RIZB & 4.27 & 4.27 & 4.3 & 14.28 & 15.22 & 14.7 & 84.50 & 85.80 & 85.15 & 57.12 & 60.89 & 59.00 & 3.29 & 3.51 & 3.4 \\
\hline & MIX & 7.82 & 6.76 & 7.3 & 16.88 & 20.00 & 18.4 & 95.77 & 95.77 & 95.77 & 67.52 & 80.00 & 73.76 & 3.89 & 4.61 & 4.25 \\
\hline \multicolumn{2}{|c|}{ Mean } & 5.16 & 4.98 & 5.1 & 15.12 & 16.72 & 15.9 & 86.78 & 86.99 & 86.88 & 60.47 & 66.89 & 63.68 & 3.48 & 3.82 & 3.65 \\
\hline \multirow{3}{*}{5} & CONT. & 4.98 & 4.98 & 5.0 & 14.84 & 18.67 & 16.7 & 92.30 & 93.60 & 92.95 & 59.36 & 74.67 & 67.01 & 3.42 & 4.15 & 3.78 \\
\hline & RIZB & 5.33 & 5.51 & 5.4 & 18.24 & 20.67 & 19.4 & 97.07 & 97.50 & 97.28 & 72.96 & 82.67 & 77.81 & 4.20 & 4.76 & 4.48 \\
\hline & MYCO & 6.22 & 6.76 & 6.5 & 22.88 & 21.67 & 22.2 & 101.40 & 101.83 & 101.61 & 91.40 & 86.67 & 89.03 & 5.26 & 4.99 & 5.12 \\
\hline 0.05 & Bio & 0.91 & 0.89 & 0.9 & 0.95 & 1.69 & 1.32 & 1.19 & 1.21 & 1.2 & 3.47 & 6.76 & 5.11 & 0.20 & 0.38 & 0.29 \\
\hline
\end{tabular}

\section{5- Biological performance:}

Mycorrhizal Infection: Table 8 indicated significant increase in mycorrhizal infection in roots of plant grown without Mo treatment as a result of RIZB, MYCO or mixed RIZB/MYCO treatment. The highest percentage $(60.78 \%)$ was due to mixed RIZB/MYCO treatment and the lowest (49.0\%) was due to MYCO treatment as compared to the control $(42.46 \%)$. Similar trend was recorded for plants grown with Mo foliar application but with higher values due to Mo application. As an overall mean value, mycorrhizal percentage of plants grown without Mo was $49.34 \%$, and in plants grown with Mo was $57.47 \%$ (Table 8 and Fig 6A). MYCO treatment enhanced $\mathrm{P}$ availability, thus VA-mycorrhizal fungi stimulated the growth of plants by improving their ability to recover $\mathrm{P}$ from $\mathrm{P}$-deficient soils. These data are in agreement with those reported by Johansson et al., (2004).

Nodulation: The results in Table 8 showed significant increase in number of nodules in plant grown without Mo treatment as a result of treatment by RIZB, MYCO or mixed RIZB/MYCO. The highest nodules number (32.0 per plant) was due to treatment by mix RIZB/MYCO and the lowest (19.0 per plant) was due to MYCO treatment as compared to the control (13.3 per plant). Root of plants grown with Mo foliar application 
showed higher nodulation than those of plants grown without Mo, and treated by RIZB, MYCO, mix $\mathrm{RIZB/MYCO}$. As an overall mean value, the number of nodules per plant due to Mo treatment was 31.0/plant while without Mo it was 22.4/plant (Table 8).

The nodules weight per plant significantly increased as a result of RIZB, MYCO or mix RIZB/MYCO treatment without Mo treatment (Table 8). Plants grown with Mo showed significant high nodules weight (overall mean value of $1.2 \mathrm{~g} / \mathrm{plant}$ ) as compared to those without Mo (overall mean value of $0.645 \mathrm{~g} / \mathrm{plant}$ ). These results indicate that the positive interaction combination of biofertilizer with Mo had stimulated the numbers and weights of nodule in roots of Faba bean grown in sandy soil. These results agreed with the findings of Rabie and Almadini (2005) who found that mycorrhiza increased number of nodulation, efficacy of $\mathrm{N}$-fixation by Rhizobium and nutrient uptake. ElWakeil and El-Sebai (2007) found that there was a significant positive effect of rhizobia on the number and weight of nodules compared to NPK fertilizer. Mandou et al., (2017) also found that nodulation was stimulated through the combination of rhizobia with molybdenum.

Nitrogenase activity: Table 8 showed significant increase in the activity of nitrogenase without Mo treatment due to application of biofertilizer: RIZB, MYCO or mix RIZB/MYCO. The highest activity
(3.035 nmol $\mathrm{C}_{2} \mathrm{H}_{5} \mathrm{~g}^{-1}$ plant $\mathrm{h}^{-1}$ ) was obtained due to mix RIZB/MYCO treatment and the lowest $(1.25 \mathrm{nmol}$ C2H5 g-1 plant h-1) was due to MYCO treatment. Similar trend was found with Mo foliar application with biofertilizer treatments. As an overall mean value, nitrogenase activity was the highest $(4.505 \mathrm{nmol} \mathrm{C} 2 \mathrm{H} 5$ g-1 plant h-1) with foliar spray by Mo in combination with RIZB, MYCO, or mix RIZB/MYCO than without Mo treatment (1.695 nmol C2H5 g ${ }^{-1}$ plant $^{-1}$ ).

These data point out to the significant positive effects of Mo and biofertilizer treatments for improving nitrogenase activity in soil as compared to without Mo treatment but treated by biofertilizer. This indicates the effective role of Mo in enhancement nitrogenase activity in soil. Fig 6 B. showed that mix RIZB/MYCO was the most effective treatment followed by RIZB without Mo or with Mo treatment. Consequently, foliar application of Mo was effective for increasing nitrogenase activity. These data agree with those found by Mohamed (2015) who noted that plant shoot dry weight, uptake of nitrogen and $\mathrm{P}$ by the shoots as well as nodulation and nitrogenase activity of Faba bean roots were improved by inoculation with G. mosseae. Crusciol et al., (2019) found that nitrogenase activity was greater with inoculation than without.

Table 8. Biological performance under drip irrigation as influenced by biofertilizers treatments without and with of Mo application in the two growing seasons of Faba bean plant

\begin{tabular}{|c|c|c|c|c|c|c|c|c|c|c|c|c|c|}
\hline \multirow{2}{*}{\multicolumn{2}{|c|}{ Treatments }} & \multicolumn{3}{|c|}{ Myco. infection (\%) } & \multicolumn{3}{|c|}{ Nodules No./ plant } & \multicolumn{3}{|c|}{ Nodules wt. (g/plant) } & \multicolumn{3}{|c|}{$\begin{array}{c}\text { Nitrogenase activity } \\
\left(\text { nmol } \mathbf{C}_{2} \mathrm{H}_{5} \mathbf{g}^{-1} \text { plant } \mathbf{h}^{-1}\right)\end{array}$} \\
\hline & & \multirow{2}{*}{$\begin{array}{l}2016 / \\
2017\end{array}$} & \multirow{2}{*}{$\begin{array}{l}2017 / \\
2018\end{array}$} & \multirow{2}{*}{ Mean } & \multirow{2}{*}{$\begin{array}{l}2016 / \\
2017\end{array}$} & \multirow{2}{*}{$\begin{array}{l}2017 / \\
2018\end{array}$} & \multirow{2}{*}{ Mean } & \multirow{2}{*}{$\begin{array}{l}2016 / \\
2017\end{array}$} & \multirow{2}{*}{$\begin{array}{l}2017 / \\
2018\end{array}$} & \multirow{2}{*}{ Mean } & \multirow{2}{*}{$\begin{array}{l}2016 / \\
2017\end{array}$} & \multirow{2}{*}{$\begin{array}{l}2017 / \\
2018\end{array}$} & \multirow{2}{*}{ Mean } \\
\hline Mo mg/l & Bio & & & & & & & & & & & & \\
\hline \multirow{4}{*}{0} & CONT. & 41.83 & 43.10 & 42.46 & 13.33 & 13.33 & 13.3 & 0.40 & 0.40 & 0.40 & 0.69 & 0.74 & 0.715 \\
\hline & RIZB & 44.43 & 45.83 & 45.13 & 24.33 & 26.67 & 25.5 & 0.76 & 0.80 & 0.78 & 1.70 & 1.87 & 1.785 \\
\hline & MYCO & 48.60 & 49.40 & 49.0 & 18.00 & 20.00 & 19.0 & 0.46 & 0.58 & 0.52 & 0.80 & 1.70 & 1.250 \\
\hline & MIX & 60.10 & 61.47 & 60.78 & 30.67 & 33.33 & 32.0 & 0.81 & 0.94 & 0.875 & 3.20 & 2.87 & 3.035 \\
\hline \multicolumn{2}{|c|}{ Mean } & 48.74 & 49.95 & 49.34 & 21.58 & 23.33 & 22.4 & 0.61 & 0.68 & 0.645 & 1.60 & 1.79 & 1.695 \\
\hline \multirow{4}{*}{5} & CONT. & 46.20 & 47.70 & 46.95 & 22.00 & 22.67 & 22.3 & 0.80 & 0.79 & 0.795 & 1.70 & 1.77 & 1.735 \\
\hline & RIZB & 51.10 & 54.33 & 52.71 & 33.33 & 37.00 & 35.2 & 1.30 & 1.41 & 1.355 & 2.53 & 2.86 & 2.695 \\
\hline & MYCO & 59.60 & 62.73 & 61.16 & 25.67 & 26.67 & 26.2 & 0.92 & 1.02 & 0.97 & 1.85 & 1.94 & 1.895 \\
\hline & MIX & 68.37 & 69.70 & 69.03 & 40.33 & 40.67 & 40.5 & 1.65 & 1.71 & 1.68 & 11.70 & 11.70 & 11.70 \\
\hline \multicolumn{2}{|c|}{ Mean } & 56.32 & 58.62 & 57.47 & 30.33 & 31.75 & 31.0 & 1.17 & 1.23 & 1.20 & 4.44 & 4.57 & 4.505 \\
\hline LSD & Mo & 1.84 & 3.17 & 2.50 & 1.85 & 2.91 & 2.38 & 0.06 & 0.09 & 0.075 & 0.15 & 0.34 & 0.245 \\
\hline 0.05 & Bio & 2.61 & 4.49 & 3.55 & 2.61 & 4.11 & 3.36 & 0.09 & 0.12 & 0.105 & 0.21 & 0.48 & 0.345 \\
\hline
\end{tabular}




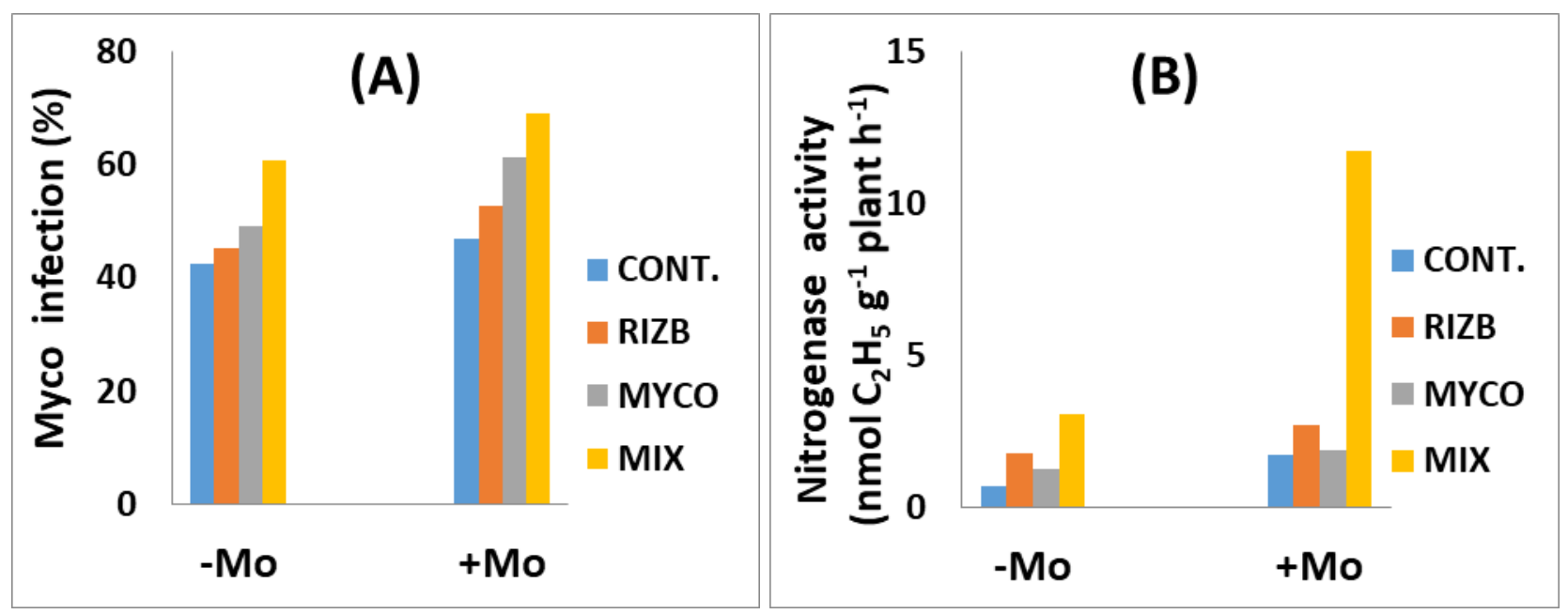

Fig. 6. (A) Mycorrhizal infection and (B) Nitrogenase activity in soil rhizosphere of Faba bean as influenced by different treatments of biofertilizers without and with Mo application (mean of two successive seasons)

\section{CONCLUSION}

This study was carried out to investigate the effect of foliar application of ammonium molybdate in combination with biological fertilizers: Mycorrhiza (Glomus sp.) and Rhizobium (Rhizobium leguminosarum) on the growth performance and productivity of Faba bean (Vicia faba L.) grown in sandy soil under drip irrigation system. The results showed positive significant effects of Mo foliar application for enhancement the growth and N, P, and K status of Faba bean. VA-mycorrhizal fungi stimulated the growth of Faba bean by improving their ability to recover $\mathrm{P}$ from the $\mathrm{P}$-deficient used soil and to improve plant growth under drip irrigation system.

Molybdenum foliar application led to producing of high values for all growth parameters compared without Mo treatment. Application of biofertilizer improved NPK, O.M. in soil and soil respiration. The most effective biofertilizer was the mixed RIZB/MYCO followed by RIZB for N, K and MYCO for P, O.M, and soil respiration. As a result, the upper soil layer (0-30 $\mathrm{cm}$ ) had high values of available N, P, O.M and soil respiration. At the same time $\mathrm{N}, \mathrm{P}$ and $\mathrm{K}$ contents in leaves and grains showed high response to addition of Mo and also to mixed RIZB/MYCO followed by RIZB treatment for $\mathrm{N}$ and protein, and $\mathrm{MYCO}$ for $\mathrm{K}$ and $\mathrm{P}$ content. Vegetative growth parameters and yield components of Faba bean showed high response to mixed RIZB/MYCO followed by MYCO treatment. It also clears that mycorrhizal infection had enhanced with MYCO treatment while Nitrogenase activity was enhanced with RIZB treatment under sandy soil condition and drip irrigation system.

\section{REFERENCES}

Abd-Alla, M.H., A.W. El-Enany., N.A. Nafady., D.M. Khalaf, and F.M. Morsy. 2013. Synergistic interaction of Rhizobium leguminosarum bv. viciae and arbuscular mycorrhizal fungi as a plant growth promoting biofertilizers for faba bean (Vicia faba L.) alkaline soil. Microbial. Res. S0944-5013(13): 117-121.

Attia, M., N.M. Awad and A.S. Turky. 2003. Bioremediation of sewaged soils through dual inoculation with arbuscular mycorrhizal fungi and Pseudomonas putida. Egypt. J. of Microbiology. 38: 337-350.

Alison, L. E. and C.D. Moodle. 1965 Carbonate. In: Methods of Soil Analysis, C.A. Black (ed.). Amer. Soc. Agron. Inc., Madison, Wisc. 1379-1396.

Badr, El. A., A. M. Wali and G. A. Amin. 2013. Effect of Sowing Dates and Biofertilizer on Growth Attributes, Yield and its Components of Two Faba Bean (Vicia faba L.) Cultivars. World Applied Sci. J. 28 (4): 494-498.

Bakry, B.A., T.A. Elewa, M.F. El-Karamany, M.S. Zeidan and M.M. Tawfik. 2011. Effect of row spacing on yield and its components of some faba bean varieties under newly reclaimed sandy soil condition. World J. Agric. Sci. 7(1): 68-72.

Bargaz, A., K. Lyamlouli, M. Chtouki, Y. Zeroual and D. Dhiba. 2018. Soil Microbial Resources for Improving Fertilizers Efficiency in an Integrated Plant Nutrient Management System. Frontiers in Microbiology www.frontiersin.org. 9 (1606):1-25.

Barman, J., A. Samanta., B. Saha and S. Datta. 2016. Mycorrhiza.The Oldest Association ,, Between Plant and Fungi. General Article. Resonance. 1093-1104.

Black, C.A., D.D. Evans., J. L. White., L.E. Ensminger and F.E. Clark. 1965. Methods of Soil Analysis. Parts 1 and 2. Amer. Soc. Agron., Inc., Madisons, Wisconsin, U.S.A. 
Bremner, J.M., and C.S. Mulvaney. 1982. Total nitrogen. In A.L. Page (eds.). Methods of soil Analysis, Part2. Chemical and Microbiological properties. Agronomy Monograph no. 9 (2 nd Edition)

Castro, L. C. Ribeiro (7) and N. R. Costa. 2019. Rhizobial Inoculation and Molybdenum Fertilization in Peanut Crops Grown in a No Tillage System After 20 Years of Pasture. Rev Bras Cienc Solo. 43: 1-19.

Chapman, H.D. and P.F. Pratt. 1961. Analysis for soils, plants, and waters. Agric. Pub., Univ. of California, Reverside, USA.

Cottenie, A., M.Verlso, L. Kilkens, G.Velghe and R. Camerlynck. 1982. Chemical Analysis of Plants and Soils. Lab. Agroch. State Univ. Gent, Belgium.

Crusciol, C. A. C., J. F. Neto, T. S. Mui, A. J. Franzluebbers, C. H. M. da Costa, G. S. A.

Deshwal, V.K., K.Vig, D.M. Amisha, P.Yadav, D. Bhattacharya and M. Verma. 2019. Synergistic effects of the inoculation with plant growth-promoting Rhizobium and Pseudomonas on the performance of Mucuna. Ann. Forestry. 19(1): 13-20.

Eduardo, C., P.A. Adelson, J.R.A. Bruno and M.G. Teixeira. 2010. Seeds enriched with phosphorus and molybdenum improves the contribution of biological nitrogen fixation to common bean as estimated by 15n isotope dilution. R. Bras. Ci. Solo. 34:1093-1101.

El Habbasha, S.F., M. Hozayn and M.A. Khalafallah. 2007. Integration effect between phosphorus levels and bio-fertilizers on quality and quantity yield of faba bean (vicia faba L.) in newly cultivated sandy soils. Res. J. of Agric. and Biol. Sci. 3 (6):966-971.

El-Wakeil, N. E. and T. N. El-Sebai. 2007. Role of Biofertilizer on Faba Bean Growth, Yield, and its Effect on Bean Aphid and the Associated Predators. Res.

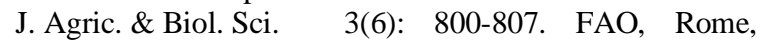
Italy.

FAO. 1970. Physical and Chemical Methods of Soil and Water Analysis. Soils Bull. No.10.

Ghorbanian, D., S. Harutyunyan, D. Mazaheri and F. Rejali. 2011. Effects of mycorrhizal symbiosis and different levels of phosphorus on yield, macro and micro elements of Zea mays L. under water stress condition. African. J. of Agric. Res. 6 (24): 5481- 5489. 26.

Giovannetti, M. and B. Mosse. 1980. An evaluation of techniques for measuring vesicular arbuscular mycorrhizal infection in roots. New phytologist. 84:489-500.

Ingraffia, R., G. Amato., A. S. Frenda1 and D. Giambalvo. 2019. Impacts of arbuscular mycorrhizal fungi on nutrient uptake, $\mathrm{N} 2$ fixation, $\mathrm{N}$ transfer, and growth in a wheat/faba bean intercropping system. PLOS ONE https://doi.org/10.1371/J. pone. 0213672:1-16

Jackson, M.L. 1973. Soil Chemical Analysis, Prentice Hall, Inc. Englewood Cliffs, N.J., J.F. Johansson, L.R. Paul and R.D. Finlay. 2004. Microbial interactions in the mcorrhizosphere and their significance for sustainable agriculture. FEMS Microbiol. Ecol. 48: 1-13.
Kafle, A., K. R. Cope, R. Raths, J. K. Yakha, S. Subramanian, H. Bücking and K. Garcia. 2019. Harnessing Soil Microbes to Improve Plant Phosphate Cropping Systems. Agronomy. 9- 127. doi:10.3390/agronomy9030127.

Kaloosh, A.A. 1978 Factor affecting carbon dioxide evolution from soils of the North- western Mediterranean coast. MSc. Thesis, Fac. Of Agric. Alexandria Univ., Egypt.

Kandil, H., N. Gad and M.T. Abdelhamid. 2013. Effects of different rates of phosphorus and molybdenum application on two varieties common bean of (Phaseolus vulgaris L.). J. Agric. Food. Tech. 3 (3):8-16.

Karkanis, A., G. Ntatsi, L. Lepse, J. A. Fernández, I. M. Vågen, B. Rewald, I. Alsin, A. Kronberga, A. Balliu, M. Olle, G. Bodner, L. Dubova, E.Rosa and D. Savvas. 2018. Faba Bean Cultivation - Revealing Novel Managing Practices for More Sustainable and Competitive European Cropping Systems. Frontiers in Plant Science | www.frontiersin.org. 9 (1115): 1-14.

Khalil, S.E., M.M. Hussein and A.M. Khalil. 2014. Interaction Effects of Different Soil Moisture levels, Arbuscular Mycorrhizal Fungi and Three Phosphate Levels on: IIMineral ions, Protein and Amino Acids contents of Garden Cress (Lepidiumsativum L.) plant. International J. of Advanced Research. 2(12) 263 -278.

Khatab, A.Kh. 2016. Improving growth, yield and nutrient uptake on Faba Bean (Vicia faba L) by inoculation with mycorrhizay and foliar application of cobalt under saline irrigation water on a calcareous soil. J. Soil Sci. and Agric. Eng., Mansoura Univ. 7 (3).

Mandou, M.S., A.H. Chotanguil, L.N. Nkot and D. Nwaga.2017. Effects of rhizobia inoculation and molybdenum application on nodulation, $\mathrm{N}$ uptake and yield of peanut (Arachis hypogaea L.). Int. J. Agron. Agri. R. 11 (1):103-113.

Marzban, Z., E. Faryab and Sh. Torabian. 2017. Effects of arbuscular mycorrhizal fungi and Rhizobium onion content and root characteristics of green bean and maize under intercropping. Acta agriculturae Slovenica. 109 (1):79-88.

Mfilinge, A, K Mtei and PA. Ndakidemi. 2014. Effects of rhizobium inoculation and supplementation with $\mathrm{P}$ and $\mathrm{K}$, on growth, leaf chlorophyll content and nitrogen fixation of bush bean varieties. American J. of Research Communication. 2(10): 49- 87.

Mohamed, A.K. 2010. Effect of sowing date, ridge direction, plant orientation and population on faba bean grain yield. 12: $11-12$

Mohamed, H.A. and A.M. Gomaa. 2005. Faba bean growth and green yield and its quality as influenced by the application of bio-organic farming system. J. of Applied Sci. Research. 1: 380-385.

Mohamed, H.M. 2015. Effect of Arbuscular Mycorrhizal Fungus (Glomus Mosseaeand Soil Yeasts Interaction on Root Nodulation, N-Fixation and Growth of Faba Bea (Vichia faba). Malaysian J. of Soil Sci. 19: 157168. 
Mona, A.M., M.A. Sabah and A.M. Rehab. 2011. Influence of potassium sulfate on faba bean yield and quality. Australian J. of Basic and Applied Sci. 5(3): 87-95.

Ndakidemi, P. A., S. Bambara and J. H.J.R. Makoi. 2011. Micronutrient uptake in common bean (Phaseolus vulgaris L.) as affected by Rhizobium inoculation, and the supply of molybdenum and lime. Plant omics J. 4(1):40-52.

Norris, D.O. and R.A. Date. 1976. Legume bacteriology. In Tropical Pasture Research. Principles and Methods. Eds N. H Shaw and W. W Bryan, Commonwealth Agricultural Bureaux. Farnham Royal, UK, Bulletin. 51: 134-174.

Okazaki, S., N. Nukui, M. Sugawara and K. Minamisawa. 2004. Rhizobial strategies to enhance symbiotic Interactions: Rhizobiotoxine and 1-Aminocyclopropane 1- Carboxylate deaminase. Microb. Environ. 19(2): 99111.

Olsen, S. R. and F.S. Watanabe. 1965. Test of an ascorbic acid method for determining phosphorus in water and $\mathrm{NaHCO} 3$ extracts from soil. Soil Sci. Soc. Amer. Proc. 29: 677-678.

Olsen, S., C. Cole., F. Watanabe and L. Dean, 1954. Estimation of available phosphorus in soils by extraction with sodium bicarbonate. USDA Circular Nr 939, US Gov. Print. Office, Washington, D.C. USA.

Page, A.L., R.H. Miller and D.R Keeney. 1982. Methods of Soil Analysis. part 2: Chemical and Microbiological Properties. Second edition. Agronomy J. 9: 2, Am. Soc. Agron. Inc., Soil Sci. Soc. Am. Inc. Pub. Madison, Wisconsin, USA.

Pandeeswari, N. and S. Kalaiarasu. 2017. Occurrence, characterization of native rhizobia and nodulat ion pattern, soil nutrient status grown in groundnut of tsunami affected coastal area of cuddalore district of tamil nadu. IJCAS. 7(2): 163-168.

Patreze, C.M. and L. Cordeiro. 2004. Nitrogen-fixing and vesicular arbuscular mycorrhizal symbioses in some tropical legume trees of tribe Mimosease, Forst Ecol. Mangt.196:275- 285.
Phillips, J.M. and D. Hayman. 1970. Improved procedures for clearing roots and staining parasitic and vesiculararbuscular mycorrhizal fungi for rapid assessment of infection. J. Transactions of the British mycological Society. 55:158-161.

Rabie, G. H. and A. M. Almadini. 2005. Role of bioinoculants in development of salt-tolerance of Vicia faba plants under salinity stress. African J. of Biotechnology. 4 (3): 210-222.

Raklami, A., N. Bechtaoui1, A. Tahiri, M. Anli, A. Meddich and K. Oufdou. 2019. Use of Rhizobacteria and Mycorrhizae Consortium in the Open Field as a Strategy for

Rizk, F.A. and M.R. Shafeek. 2000. Response of growth and yield of Vicia faba plants to foliar and bio-fertilizers. Egyptian J. of Applied Sci. 15: 652-670.

Schenck, N. C. and Y. Perez. 1990. "Manual for the identification of VA mycorrhizal fungi," Synergistic Publications Gainesville.

Schütz, L., A. Gattinger, M. Meier, A. Müller, T. Boller, P.Mäder and N. Mathimaran1. 2018. Improving Crop Yield and Nutrient Use Efficiency via fertilization - A Global Meta-analysis. Frontiers in Plant Sci. www.frontiersin.org. 8(2204): 1-13.

Snedecor, G.W. and W.G. Cochran. 1990. Statistical Methods (7th Ed.), Iowa State University Press, Ames. 507 pp.

Vafadar, F., R. Amooaghaie and M. Otroshy. 2014. Effects of plant-growth-promoting rhizobacteria and arbuscular mycorrhizal fungus on plant growth, stevioside, NPK, and chlorophyll content of Stevia rebaudiana. J. of Plant Interactions. 9(1):128-136

Vincent, J.M. 1970. A manual for the practical study of root nodule bacteria. Oxford: Black-well Sci.western Mediterranean coast. MSc. Thesis, Fac. Of Agric. Alex. Univ., Egypt.

Youseif, S. H., H. Fayrouz., Abd. Megeed and S. A. Saleh. 2017. Improvement of Faba Bean Yield Using Rhizobium/Agrobacterium Inoculant in Low-Fertility Sandy Soil. Agronomy. 7(2):1-12. 


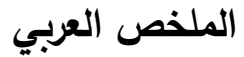

\section{تأثير التلقيح بواسطة المخصبات الحيوية والموليبدينوم على نمو وإنتاجية الفول البلدى في التربة الرملية تحت الري بالتنقيط (Vicia faba L.) \\ دلال حريمس سارى ، انجه مصطفى نايل ، نهى موسى عبد الحميد}

واوضحت معاملات التسميد الحيوى بانها تحسن من مPK و O.M و O.M و RIZB / النتائج ان أفضل معاملات التسميد الحيوى كانت يليها معاملة RIZB MYCO من N N KYCO امطت اعلى معنويه لكل من P و و soil respiration و ب.M السطحية (0-30 سم) والتحت سطحية (30-60 سم) كانت اعلى معنوية لكل من النيتروجين والفوسفور المتاح والمادة العضوية وتتفس التربة عند الطبقة السطحية (0-30 سم). بالنسبة لمحتوى العناصر بأوراق وحبوب نبات الفول البلدى

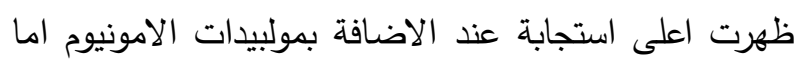
RIZB / على مستوى معاملات التسميد الحيوى كانت معاملة MYCO والتي اعطت اعلى معنوية لكل من محتوى النتروجين

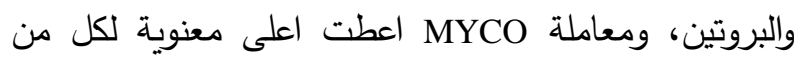

$$
\text { الفوسفور والبوتاسيوم بالأوراق والحبوب. }
$$

قياسات النمو الخضرى والإنتاجية لنبات الفول اوضحت MYCO يليها RIZB / MYCO اعلى معنوية عند معاملة MYCO بنفردها. اما القياسات البيولوجية كانت الميكوريزا معاتها Mycorrhizal Infection|تحسن من نسبة الاصابة بالميكوريزية بينما معاملة الرايزوبيا زادت من نشاط انزيم النيتروجينيز بالتربة تحت ظروف الأراضى الرملية.
اجريت تجربة حقلية خلال موسمى 2017/2016 و2018/2017 لدراسة تأثير الاضافة من مولبيدات الامونيوم مع التسميد الحيوي لكل من : (Mycorrhiza (Glomus sp) و Rhizobium (Rhizobium leguminosarum) وانتاجية الفول البلدى (Vicia faba L.) في التربة الرملية تحت نظام الري بالتنقيط ، بمنطقة البستان - مزرعة على مبارك - جنوب التحرير. وشملت المعاملات الرئيسية

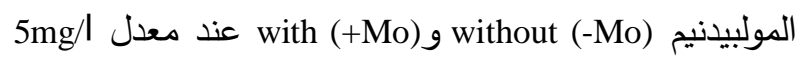
من مولبيدات الامونيوم رشا على الاوراق بينما شملت

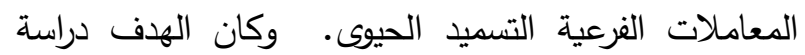
استجابة الفول البلدى للرش بموليبدات الأمونيوم فى وجود المخصبات الحيوية (الميكوريزا والريزوبيوم) على زيادة إنتاجية الفول في التربة الرملية تحت نظام الري بالتتقيط. وقد استخدم التصميم قطع منشقه مره واحده وكانت معاملات التسميد الحيوى:

Mycorrhiza (MYCO), Rhizobia (RIZB) and Mix of .both (MYCO/ RIZB)

النتائج المتحصل عليها: اوضحت النتائج بوجود تأثير معنوى نتيجة الإضافة من مولبيدات الامونيوم رشا على الاوراق حيث اظهرت تحسن فى نمو الفول واتاحة العناصر الكبرى (NPK). اما بالنسبة للتسميد الحيوي كانت الميكوريزا تحفز من نمو الفول البلدى حيث ان لها القدرة على اتاحه عنصر الفوسفور تحت ظروف الرى بالتنقيط فى ظروف الأراضى الرملية. معاملة إضافة المولبيدنيم سجلت اعلى قيم

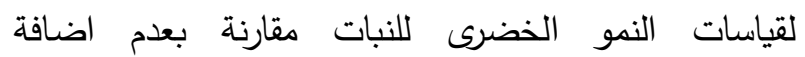

